\title{
Article \\ Natural Radionuclide Concentrations by $\gamma$-Ray Spectrometry in Granitic Rocks of the Sol Hamed Area, Southeastern Desert of Egypt, and Their Radiological Implications
}

\author{
El-Afandy H. Adel ${ }^{1}$, Mohamed G. El-Feky ${ }^{2}$, Samia H. Taha ${ }^{3,}{ }^{*}$, Salwa M. El Minyawi ${ }^{3}$, Hanaa A. Sallam ${ }^{2}$, \\ Osama A. Ebyan ${ }^{2}$, El-Sayed Yousef ${ }^{4,5}$ and Mohamed Y. Hanfi ${ }^{6,7, * \text { (D) }}$
}

check for updates

Citation: Adel, E.-A.H.; El-Feky, M.G.; Taha, S.H.; El Minyawi, S.M.; Sallam, H.A.; Ebyan, O.A.; Yousef, E.-S.; Hanfi, M.Y. Natural Radionuclide Concentrations by $\gamma$-Ray Spectrometry in Granitic Rocks of the Sol Hamed Area, Southeastern Desert of Egypt, and Their Radiological Implications. Minerals 2022, 12, 294. https:// doi.org/10.3390/min12030294

Academic Editor: Fernando P. Carvalho

Received: 26 January 2022 Accepted: 21 February 2022 Published: 26 February 2022

Publisher's Note: MDPI stays neutral with regard to jurisdictional claims in published maps and institutional affiliations.

Copyright: (c) 2022 by the authors. Licensee MDPI, Basel, Switzerland. This article is an open access article distributed under the terms and conditions of the Creative Commons Attribution (CC BY) license (https:// creativecommons.org/licenses/by/ $4.0 /)$.
1 Contracts Sector, Nuclear Materials Authority, Maadi P.O. Box 530, Cairo, Egypt; adel_elafandy@hotmail.com

2 Department of Geochemical Exploration, Research Sector, Nuclear Materials Authority, Maadi P.O. Box 530, Cairo, Egypt; mglal_99@hotmail.com (M.G.E.-F.); tays_1988@mail.ru (H.A.S.); o_ebyan@yahoo.com (O.A.E.)

3 Department of Physics, Faculty of Science, Al Azhar University, Maadi P.O. Box 11884, Cairo, Egypt; smelminyawi@gmail.com

4 Department of Physics, Faculty of Science, King Khalid University, Abha 61413, Saudi Arabia; omn_yousef2000@yahoo.com

5 Department of Physics, Faculty of Science, Al Azhar University, Assiut Branch, Assiut P.O. Box 71524, Assiut, Egypt

6 Department of Medical and Radiation Research, Research Sector, Nuclear Materials Authority, Maadi P.O. Box 530, Cairo, Egypt

7 Institute of Physics and Technology, Ural Federal University, St. Mira, 19, 620002 Yekaterinburg, Russia

* Correspondence: mthy81@yahoo.com (S.H.T.); mokhamed.khanfi@urfu.ru (M.Y.H.)

\begin{abstract}
The occurrence of heavy radioactive minerals in construction supplies such as granite has drawn attention to the extraction of heavy radioactive minerals. Granitic rocks were identified to serve an essential economic role in the study area's surrounding locations. As a result, the current study attempted to detect the activity concentrations of ${ }^{238} \mathrm{U},{ }^{232} \mathrm{Th}$, and ${ }^{40} \mathrm{~K}$ in the granitic rock samples tested and estimate the radiological dangers associated with these rocks. The obtained data on activity concentrations for ${ }^{238} \mathrm{U}(610 \pm 1730 \mathrm{~Bq} \mathrm{~kg}-1),{ }^{232} \mathrm{Th}\left(110 \pm 69 \mathrm{~Bq} \mathrm{~kg}^{-1}\right)$ and ${ }^{40} \mathrm{~K}$ $\left(1157 \pm 467 \mathrm{~Bq} \mathrm{~kg}^{-1}\right)$ in the granitic samples (GR) were higher than the recommended worldwide average. The radioactive levels found in the samples were caused by radioactive materials being altered and trapped inside granite faults. The exposure to gamma radiation from the granitic rocks were assessed via various radiological parameters, such as radium equivalent content $\left(856 \mathrm{~Bq} \mathrm{~kg}^{-1}\right)$, absorbed dose rate (Dair) in the air $(396 \mathrm{nGy} / \mathrm{h})$, and annual effective dose for either outdoor $\left(0.48 \mathrm{mSv}^{-1}\right)$ or indoor $\left(1.9 \mathrm{mSv}^{-1}\right)$. Statistical analysis was performed to detect the correlations between radioactive concentrations and radiological parameters. The radioactive effects contributed by the uranium minerals were associated with the granitic rocks. Based on the analysis, the radioactive levels in the examined granitic surpassed the acceptable limits; therefore, they are not safe to use in building and infrastructure applications and may cause adverse health effects.
\end{abstract}

Keywords: granitic rocks; $\gamma$-ray spectrometry; activity concentrations; NORM; radiological hazards

\section{Introduction}

The primary sources of natural radioactivity in the environment are terrestrial radioactivity and cosmic radiation. The human body is exposed to ionizing radiation from naturally occurring radioactive materials (NORM). People can be exposed to terrestrial radiation by two main approaches. First is external exposure to gamma radiation emitted from ${ }^{238} \mathrm{U},{ }^{232} \mathrm{Th}$, and ${ }^{40} \mathrm{~K}$. The second is internal exposure from inhaled radon gas and its daughters [1-4]. According to the Agency for Toxic Substances and Disease Registry (ATSDR), long-term radioactive exposure causes significant ailments that include oral necrosis, chronic lung disease, leukopenia, and anemia [5,6]. 
In recent years, multiple investigations of high natural background areas around the world have achieved more awareness in risk appraisal due to whole-body exposures of inhabitants to long-term low-level radiation [7]. Previous research has shown that high levels of radiation are caused by the presence of radionuclides in high concentrations in granite rocks, soils, sediments, and other materials. Granite rocks and sediments, among other geological elements, play an essential role in construction materials and other infrastructure applications [8,9], aside from the radioactivity moving from one zone to the next and accumulating $[10,11]$. As a result, several researchers have found that national surveys conducted around the world in recent decades have yielded distinguishing results in terms of detecting natural radionuclides in granite rocks and sediments [12-14].

The Sol Hamed granites are low to moderate circular relief hills with a hollow structure and extensive weathering. These granitic rocks are divided into two primary intrusions: coarse-grained granite with a pinkish-grey tint and fine-grained granite with a grey color. Quartz, K-feldspar, plagioclase, and biotite make up the mineral. Apatite, zircon, magnetite, and pyrite are examples of accessory minerals. The latter material is frequently oxidized and removed, leaving cubic-shaped vugs and patches of red hematite in its place. Another phase of granitic intrusion, extensively worn reddish to fine-grained pink granite, intrudes on the coarse-grained granite. This granitic appears as a thin peripheral strip with limited exposure and in batches that crosscut the previously formed granite. Quartz, K-feldspar, plagioclase, biotite, and muscovite are the primary minerals in fine-grained granite. Accessory minerals include apatite, zircon, titanite, and ilmenite. According to geochemical evidence, both varieties of Sol Hamed granites were formed from K-rich calc-alkaline magma. Manganese oxides can be found in stains at joints, fractures, and dispersions within the rock [10].

In comparison to the many places researched in Egyptian deserts, the investigated area was chosen for the examination task because of the economic value of the heavy minerals accumulated in granite and sedimentary rocks. Generally, the granitic rocks in the studied area are highly weathered, jointed, and cavernous. The intensity of the weathering and development of the cavernous shapes is directly related to the percentage of biotite and muscovite content, and the fracturing intensity. The present work is unique in that it detected radioactive levels in the analyzed granitic, which can be used in building materials and infrastructure applications. Various radioactive parameters were identified in addition to the evaluation of public exposure to radiation via the analysis of radiological dangers. Radium equivalent activity $\left(\mathrm{Ra}_{\mathrm{eq}}\right)$ absorbed dose rate $\left(\mathrm{D}_{\text {air }}\right)$, annual effective dose (AED), external $\left(\mathrm{H}_{\mathrm{ex}}\right)$, and internal $\left(\mathrm{H}_{\mathrm{in}}\right)$ hazard indices were some of the radiological risks. In addition, the annual gonadal dose equivalent (AGDE) and the excess lifetime cancer risk (ELCR) were computed.

\section{Materials and Methods}

\subsection{Geological Setting}

One of the most important areas of the Eastern Desert of Egypt is the Sol Hamed area. It is located in the southern Eastern Desert of Egypt, about $40 \mathrm{~km}$ to the north from the Egyptian Sudanese borders, between latitude $22^{\circ} 16^{\prime} 40^{\prime \prime}-22^{\circ} 18^{\prime} 30^{\prime \prime} \mathrm{N}$ and longitude $36^{\circ} 14^{\prime} 20^{\prime \prime}-36^{\circ} 16^{\prime} 30^{\prime \prime} \mathrm{E}$, at a distance of about $30 \mathrm{~km}$ southwest of Abu Ramad city, on the Red Sea. The study area is low, and has moderate to high relief and is remarked by Gabal El Sela $(557 \mathrm{~m})$ and scattered isolated hills separated by sand and gravels of wadi deposits. The Sol Hamed area lies in the southern half of the Elba topographic sheet, a southeastern desert of Egypt that includes metagabbros, while the surrounding areas contain muscovite granites, mica granites, metavolcanicalsts, younger metavolcanics, older metavolcanics, serpentinites, and related rocks (Figure 1 [15]). It is part of the late Precambrian-early Paleozoic Pan-African Orogeny that formed the Arabian Nubian Shield (950-450 Ma), and covers an area of around $73.5 \mathrm{~km}^{2}$. The Sol Hamed area forms an elongated belt trending NNW-SSE. The main valleys dissecting the area are the Eikwan valley and Yoider valley. 


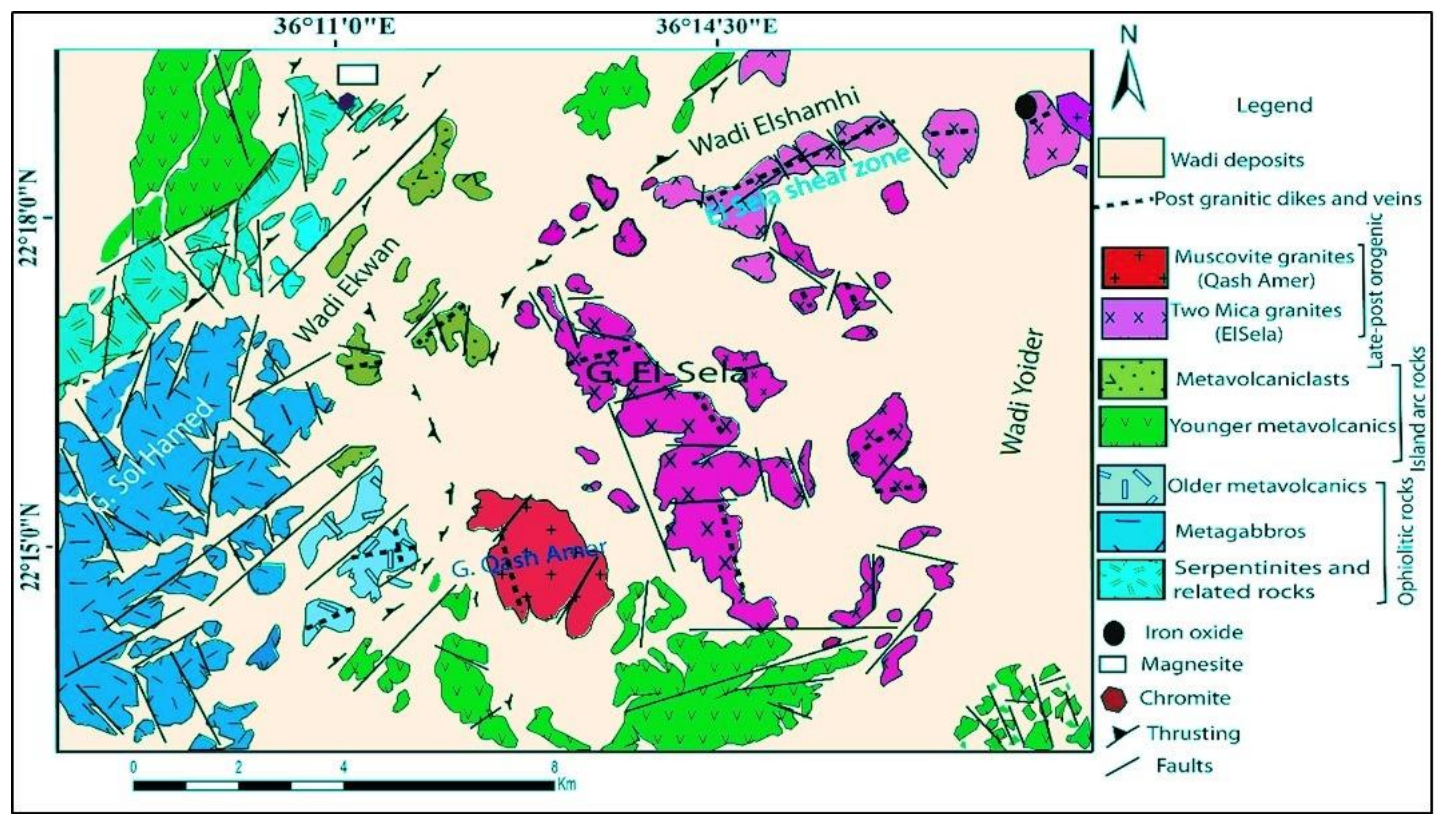

Figure 1. Geologic map of Sol Hamed area modified after [15].

\subsection{Sampling and Radioactive Detection}

Different kinds of granitic rocks (coarse grained granite (CG), fine-grained granite (FG), bostonite (B), and lamprophyre (L)), in addition to lamprophyre dykes, were observed in the Sol Hamed area. Nine samples for each granite were collected from the Sol Hamed area. Then, the crushing and sieving processes were carried out to prepare the samples for radioactive measuring. About $250 \mathrm{~g}$ of the granite rocks were inserted into a plastic container and stored for 30 days to achieve the radioactive equilibrium between radium and its daughters.

For radiation detection and measurements in granitic rock (GR) samples, a NaI crystal detector combined with a high-voltage-driven photomultiplier tube (PMT) (manufacturer, city and country) was utilized due to its quick, nondestructive, and highly efficient nature. A Gamma spectrometer (state manufacturer, city and country) with a $76 \times 76 \mathrm{~mm}^{2} \mathrm{NaI}$ (Tl) crystal was applied to detect the radioactive concentrations of ${ }^{238} \mathrm{U},{ }^{232} \mathrm{Th}$, and ${ }^{40} \mathrm{~K}$. A spectroscopy amplifier and a multichannel analyzer were part of the pulse data and management analysis equipment, which was coupled to computer with a SPTR-ATC software (AT-1315) The ${ }^{238} \mathrm{U},{ }^{232} \mathrm{Th}$, and ${ }^{40} \mathrm{~K}$ had gamma energies of $1764 \mathrm{keV}(\mathrm{I}=15.30 \%)$ from ${ }^{214} \mathrm{Bi}, 2614 \mathrm{keV}(\mathrm{I}=99.754 \%)$ from ${ }^{208} \mathrm{Ti}$, and $1460 \mathrm{keV}(\mathrm{I}=10.66 \%)$ from ${ }^{40} \mathrm{~K}[16,17]$. Approved reference materials such as RGU-1, RGTh-1, and RGK-1 were used, and their densities after pulverization were comparable to the densities of the building materials. The gamma rays released by the granitic rock samples were detected by a NaI detector, and their spectra were examined using SPTR-ATC software (AT-1315). The activity concentration for each granitic sample was determined from the intensity of the spectral line, taking into account geometry, mass, coupling time, and detector performance. An empty sealed vessel with the same dimensions was introduced into the spectrometer assembly to scrutinize the background radiation. The efficiency of the calibration was performed as follows: the container was designed while assuming that the radioactivity in the measurement samples was uniformly dispersed. The minimum detection activity (MDA)s of 2, 4, and $12 \mathrm{~Bq} \mathrm{~kg}^{-1}$ for ${ }^{238} \mathrm{U},{ }^{232} \mathrm{Th}$, and ${ }^{40} \mathrm{~K}$, respectively, were used in the granitic samples, which were calculated up to $2000 \mathrm{~s}$. The error-propagation equation for systematic and random measurement errors was used to estimate the general uncertainty of radiation levels. Efficiency of the calibration had systematic errors from 0.5 to $2 \%$, while radioactivity values had random errors of up to $5 \%$ [18]. Table 1 illustrates the radiological hazard parameters 
computed based on the activity concentrations of ${ }^{238} \mathrm{U},{ }^{232} \mathrm{Th}$, and ${ }^{40} \mathrm{~K}$, and presents the mathematical formulas used.

Table 1. Important radiological parameters and indices.

\begin{tabular}{|c|c|c|c|}
\hline Parameter & Symbol & Definition & Formula \\
\hline $\begin{array}{l}\text { Radium equivalent } \\
\text { activity }\end{array}$ & $\mathrm{Ra}_{\mathrm{eq}}$ & $\begin{array}{l}\text { Radium equivalent activity is a weighted sum of the } \\
{ }^{226} \mathrm{Ra},{ }^{232} \mathrm{Th} \text {, and }{ }^{40} \mathrm{~K} \text { activities according to the } \\
\text { hypothesis that } 370 \mathrm{~Bq} \mathrm{~kg}{ }^{-1} \text { of }{ }^{226} \mathrm{Ra}, 259 \mathrm{~Bq} / \mathrm{kg} \text { of } \\
{ }^{232} \mathrm{Th} \text {, and } 4810 \mathrm{~Bq} / \mathrm{kg}^{40}{ }^{40} \mathrm{~K} \text { attain the same dose } \\
\text { rates of gamma rays. }\end{array}$ & $\operatorname{Ra}_{\mathrm{eq}}\left(\mathrm{Bq} \mathrm{kg}^{-1}\right)=A_{R a}+1.43 A_{T h}+0.077 A_{K}$ \\
\hline External hazard index & $\mathrm{H}_{\mathrm{ex}}$ & $\begin{array}{l}\text { The external hazard index comprises the radiological } \\
\text { parameters applied to assess of the hazard of } \\
\qquad \gamma \text {-radiation }\end{array}$ & $\mathrm{H}_{\mathrm{ex}}=\frac{A_{U}}{370}+\frac{A_{T h}}{259}+\frac{A_{K}}{4810}$ \\
\hline Internal hazard index & $\mathrm{H}_{\text {in }}$ & $\begin{array}{l}\text { The internal hazard index is applied to the internal } \\
\text { exposure from radon and its decay products. } \\
\text { The other index used to estimate the level of }\end{array}$ & $\mathrm{H}_{\mathrm{in}}=\frac{A_{U}}{185}+\frac{A_{T h}}{259}+\frac{A_{K}}{4810}$ \\
\hline Radiation level index & $\mathrm{I} \gamma$ & $\begin{array}{l}\gamma \text {-radiation hazard associated with the natural } \\
\text { radionuclides in the samples was suggested by a } \\
\text { group of experts due to the different combinations of } \\
\text { specific natural activities in the sample. }\end{array}$ & $\mathrm{I}_{\gamma}=\frac{A_{R a}}{150}+\frac{A_{T h}}{100}+\frac{A_{K}}{1500}$ \\
\hline Absorbed dose rate & $\mathrm{D}(\mathrm{nGy} / \mathrm{h})$ & $\begin{array}{l}\text { The absorbed dose rate is the radioactive factor that } \\
\text { was applied to detect the effect of gamma radiation at } \\
1 \mathrm{~m} \text { from the radiation sources in the air due to the } \\
\text { concentrations of }{ }^{238} \mathrm{U},{ }^{232} \mathrm{Th} \text {, and }{ }^{40} \mathrm{~K}\end{array}$ & $\mathrm{D}_{\text {air }}\left(\mathrm{nGy} \mathrm{h}^{-1}\right)=0.430 A_{U}+0.666 A_{T h}+0.042 A_{K}$ \\
\hline $\begin{array}{l}\text { Outdoor annual effective } \\
\text { dose }\end{array}$ & AEDout & $\begin{array}{l}\text { The annual effective dose is a radioactive factor } \\
\text { utilized to detect the exposure level for radiation }\end{array}$ & $\begin{array}{l}\mathrm{AED}_{\text {out }}(\mathrm{mSv} / \mathrm{y})=\mathrm{D}_{\text {air }}(\mathrm{nGy} / \mathrm{h}) \times 0.2 \times 8760 \\
(\mathrm{~h} / \mathrm{y}) \times 0.7(\mathrm{~Sv} / \mathrm{Gy}) \times 10^{-6}(\mathrm{mSv} / \mathrm{nGy})\end{array}$ \\
\hline Indoor annual effective dose & AEDin & during a stationary duration (1 year). & $\begin{array}{c}\mathrm{AED}_{\text {in }}(\mathrm{mSv} / \mathrm{y})=\mathrm{D}_{\text {air }}(\mathrm{nGy} / \mathrm{h}) \times 0.8 \times 8760(\mathrm{~h} / \mathrm{y}) \\
\times 0.7(\mathrm{~Sv} / \mathrm{Gy}) \times 10^{-6}(\mathrm{mSv} / \mathrm{nGy})\end{array}$ \\
\hline $\begin{array}{l}\text { Annual gonadal dose } \\
\text { equivalent }\end{array}$ & AGDE & $\begin{array}{l}\text { The annual gonadal dose equivalent is the radioactive } \\
\text { parameter used to estimate the doses absorbed by the } \\
\text { gonads due to exposure to gamma radiation. }\end{array}$ & $\operatorname{AGDE}\left(\mathrm{mSv} \mathrm{y}^{-1}\right)=3.09 A_{R a}+4.18 A_{T h}+0.314 A_{K}$ \\
\hline Excess lifetime cancer risk & ELCR & $\begin{array}{c}\text { Excess lifetime cancer risk is the radioactive factor } \\
\text { applied to detect fatal cancer resulting from gamma } \\
\text { radiation exposure. }\end{array}$ & $\mathrm{ELCR}=\mathrm{AED}_{\text {out }} \times \mathrm{DL} \times \mathrm{RF}$ \\
\hline
\end{tabular}

\section{Results}

\subsection{Petrographic Investigation}

The radioactive minerals were mainly represented by uraninite, uranophane, thorianite, monazite, and columbite. Uraninite was detected in the samples collected from the Sol Hamed altered granites. Uraninite is always present where economic uranium mineralization occurs [19]. Under polarized light, uraninite appears as cubes smaller than one millimeter that are randomly scattered throughout the host and sometimes partly altered to uranophane in the highly ferruginated portion of the rock (Figure 2).

Uranophane is considered one of the most important economic-secondary uranium deposits. It is a monoclinic uranyl silicate mineral fairly common in the oxidized zone of most deposits [20]. In the present study, uranophane occurred as films, patches, and crusts, either on outcrops or in fractures. They were massive mineralizations with platy and granular forms, and showed dull, greasy, and/or waxy luster. Their colors ranged from beautiful canary yellow to lemon, but pale yellow films were common. They occurred either in discrete forms or as an alteration product of pitchblende in the form of core and periphery replacements.

Thorianite is a rare mineral, and may contain up to about $12 \%$ thorium oxide. Thorium occurs in several minerals, including thorite $\left(\mathrm{ThSiO}_{4}\right)$, thorianite $\left(\mathrm{ThO}_{2}+\mathrm{UO}_{2}\right)$, and monazite. Macroscopically, it is nearly opaque, being transparent in thin fragments. In transmitted light, it is yellowish-orange, red, brownish-yellow, brownish-black, or black.

Monazite, which is considered one of the most important sources of rare earth elements, is enriched in thorium and uranium. Monazite occurs as egg-shaped crystals ranging in color from lemon yellow to honey yellow, and sometimes red as a result of staining with iron oxides.

Columbite occurs as an alteration product phase in the Sol Hamed shear zone, brownish- to yellowish-dark grey in color. Rare metal minerals of mineralized altered granites within El Sela shear zones are columbite-tantalite minerals as ferrocolumbite, pyrochlore, and fergusonite; Th-minerals (cheralite, uranothorite, and huttonite monazite), Hf-zircon; monazite; and xenotime [21]. 

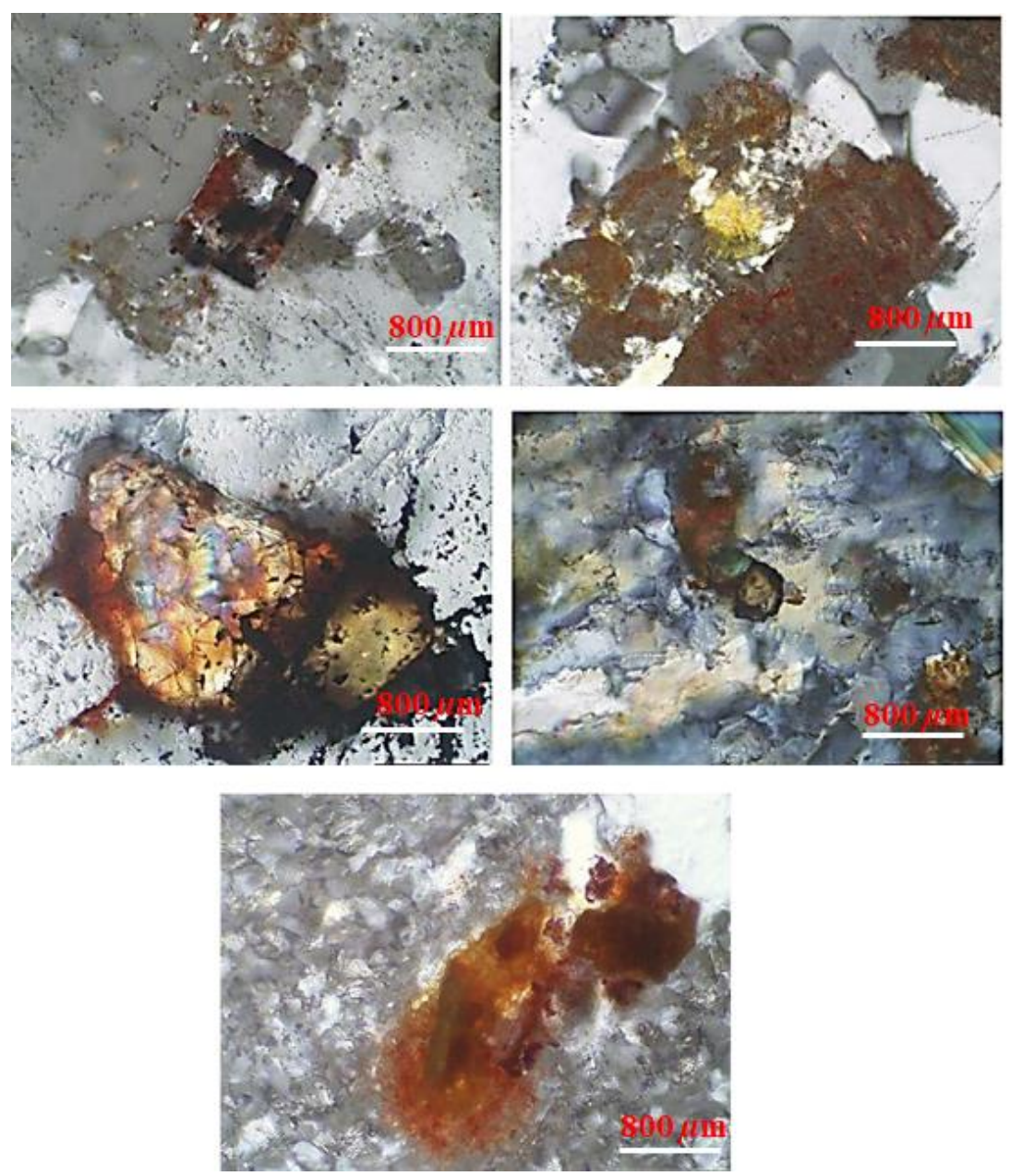

Figure 2. Photomicrographs showing uraninite, uranophane, thorianite, monazite, and columbite minerals in the Sol Hamed granite.

\subsection{Radioactivity Analysis}

The coarse-grained granite phase was characterized by radioelement contents ranging from 1.3 to $53.6 \mathrm{ppm}$ for $\mathrm{eU}$ with a mean value of $11.9 \mathrm{ppm}$, from 5 to $57.6 \mathrm{ppm}$ for eTh with a mean value of $27.5 \mathrm{ppm}$, and from $1.5 \%$ to $6.3 \%$ for $\mathrm{K}$ with mean value of $3.8 \%$ (Table 2). The remobilization parameter (eU- eTh/3.5) ranged from-6.5 to 37.1 with a mean value of 4 .

The fine-grained granite had radioelement contents ranging from 1.2 to $42.1 \mathrm{ppm}$ for $\mathrm{eU}$ with a mean value of $14.4 \mathrm{ppm}$, from 7.8 to $50.2 \mathrm{ppm}$ for eTh with a mean value of $29 \mathrm{ppm}$, and from $2.1 \%$ to $5.3 \%$ for $\mathrm{K}$ with a mean value of $4 \%$. The remobilization parameter (eU-eTh/3.5) ranged from-4.9 to 31 with a mean value of 6.2.

The bostonite dykes had concentrations ranging from 2.8 to $49.5 \mathrm{ppm}$ for eU with a mean value of $21.6 \mathrm{ppm}$, from 13.4 to $57.4 \mathrm{ppm}$ for eTh with a mean value of $32.6 \mathrm{ppm}$, and from 2.9 to $6.3 \%$ for $\mathrm{K}$ with a mean value of $4.3 \%$. The (eU- eTh/3.5) ranged from- 0.4 to 33.1 with a mean value of 12.3 .

The eU, eTh, and $\mathrm{K}$ values for lamprophyre dykes ranged from 2.2 to $760 \mathrm{ppm}$, from 1.2 to $44.7 \mathrm{ppm}$, and from $0.1 \%$ to $4.7 \%$, with mean values of $149.7 \mathrm{ppm}, 19.2 \mathrm{ppm}$, and $2.8 \%$, respectively. The (eU- eTh/3.5) ranged from 1.9 to 750 with a mean value of 144.3 .

The obtained results for the Sol Hamed granitic area revealed that the lamprophyre dykes had the highest mean value for ${ }^{238} \mathrm{U}(149.7 \mathrm{ppm})$, while the highest mean values for ${ }^{232} \mathrm{Th}$ and ${ }^{40} \mathrm{~K}$ were recorded in the bostonite dykes (32.6 ppm, $4.3 \%$ ). 
Table 2. Values of eU (ppm), eTh (ppm), and K (\%), as well as eTh/eU and eTh/K ratios and (eUeTh/3.5) parameter for the Sol Hamed granitic rocks.

\begin{tabular}{|c|c|c|c|c|c|c|}
\hline Rock Type & eU (ppm) & eTh (ppm) & eK (\%) & eTh/eU & eTh/eK & eU-eTh/3.5 \\
\hline \multirow{9}{*}{ CG } & 1.4 & 10.5 & 2.4 & 7.5 & 4.4 & -1.6 \\
\hline & 53.6 & 57.6 & 6.3 & 1.1 & 9.1 & 37.1 \\
\hline & 6.52 & 23.7 & 3.8 & 3.63 & 6.2 & -0.3 \\
\hline & 1.3 & 9.4 & 2.1 & 7.23 & 4.5 & -1.4 \\
\hline & 9.9 & 57.4 & 5.6 & 5.8 & 10.3 & -6.5 \\
\hline & 5.33 & 26.4 & 4 & 4.9 & 6.6 & -2.2 \\
\hline & 2.1 & 5 & 1.5 & 2.2 & 3.3 & 0.7 \\
\hline & 20 & 38.5 & 5.5 & 1.9 & 7.0 & 9 \\
\hline & 6.5 & 19 & 3.3 & 2.9 & 5.8 & 1.1 \\
\hline \multirow[t]{5}{*}{ Ave. } & 11.9 & 27.5 & 3.8 & 4.2 & 6.3 & 4 \\
\hline & 2.3 & 13.5 & 3 & 5.9 & 4.5 & -1.6 \\
\hline & 42.1 & 38.9 & 5.1 & 0.9 & 7.6 & 31 \\
\hline & 7.6 & 24.6 & 4 & 3.2 & 6.1 & 0.6 \\
\hline & 1.2 & 12 & 2.4 & 10 & 5 & -2.2 \\
\hline \multirow[t]{5}{*}{ FG } & 9.1 & 49 & 5.2 & 5.4 & 9.4 & -4.9 \\
\hline & 6.56 & 36 & 4.5 & 5.5 & 7.9 & -3.7 \\
\hline & 6.49 & 7.8 & 2.1 & 1.2 & 3.7 & 4.3 \\
\hline & 40 & 50.2 & 5.3 & 1.3 & 9.5 & 25.7 \\
\hline & 14.5 & 28.7 & 3.9 & 1.9 & 7.4 & 6.3 \\
\hline \multirow[t]{5}{*}{ Ave. } & 14.4 & 29 & 4 & 3.9 & 6.8 & 6.2 \\
\hline & 2.8 & 13.4 & 3 & 4.8 & 4.5 & -1 \\
\hline & 39.1 & 53.3 & 5.8 & 1.4 & 9.2 & 23.9 \\
\hline & 19 & 25 & 3.8 & 1.3 & 6.6 & 11.9 \\
\hline & 11.2 & 23.5 & 3.9 & 2.1 & 6 & 4.5 \\
\hline \multirow[t]{5}{*}{ B } & 30 & 47.1 & 5.2 & 1.6 & 9.1 & 16.5 \\
\hline & 3.9 & 15 & 3 & 3.9 & 5 & -0.4 \\
\hline & 49.5 & 57.4 & 6.3 & 1.2 & 9.1 & 33.1 \\
\hline & 26 & 30.5 & 2.9 & 1.2 & 10.5 & 17.3 \\
\hline & 13.2 & 28.3 & 4.4 & 2.1 & 6.4 & 5.1 \\
\hline \multirow[t]{5}{*}{ Ave. } & 21.6 & 32.6 & 4.3 & 2.2 & 7.4 & 12.3 \\
\hline & 2.2 & 1.2 & 0.1 & 0.6 & 24 & 1.9 \\
\hline & 760 & 34.9 & 4.5 & 0.1 & 7.8 & 750 \\
\hline & 40.3 & 15.2 & 2.6 & 0.4 & 5.8 & 35.9 \\
\hline & 6 & 4.1 & 1.7 & 0.7 & 2.4 & 4.8 \\
\hline \multirow[t]{5}{*}{$\mathrm{L}$} & 68.2 & 44.7 & 4.3 & 0.7 & 10.4 & 55.4 \\
\hline & 420.5 & 35.5 & 4.7 & 0.1 & 7.6 & 410.4 \\
\hline & 26 & 16.6 & 2.8 & 0.6 & 5.9 & 21.3 \\
\hline & 4.2 & 3.9 & 1.5 & 0.9 & 2.6 & 3.1 \\
\hline & 20.3 & 16.8 & 2.6 & 0.8 & 6.5 & 15.5 \\
\hline Ave. & 149.7 & 19.2 & 2.8 & 0.5 & 8.1 & 144.3 \\
\hline Earth's crust & 2.9 & 10.8 & 2.7 & & & \\
\hline Safety for building & 4 & 12.3 & 1.6 & & & \\
\hline
\end{tabular}

The lowest mean value for ${ }^{238} \mathrm{U}$ was observed for the coarse-grained granite (11.9 ppm), while the lowest mean values for ${ }^{232} \mathrm{Th}$ and ${ }^{40} \mathrm{~K}$ were observed in the lamprophyre dykes (19.2 ppm, and 2.5\%).

A general review of the average values for $\mathrm{eU}$, eTh, and $\mathrm{K}$ obtained for different rock types from El Sela area clarified high radioactivity levels. These figures were greater than those published for the Earth's crust, and they were also higher than the safety standards for building materials. The frequency distributions of activity concentrations of the studied radionuclides confirmed these results, as shown in Figures 3-6. 

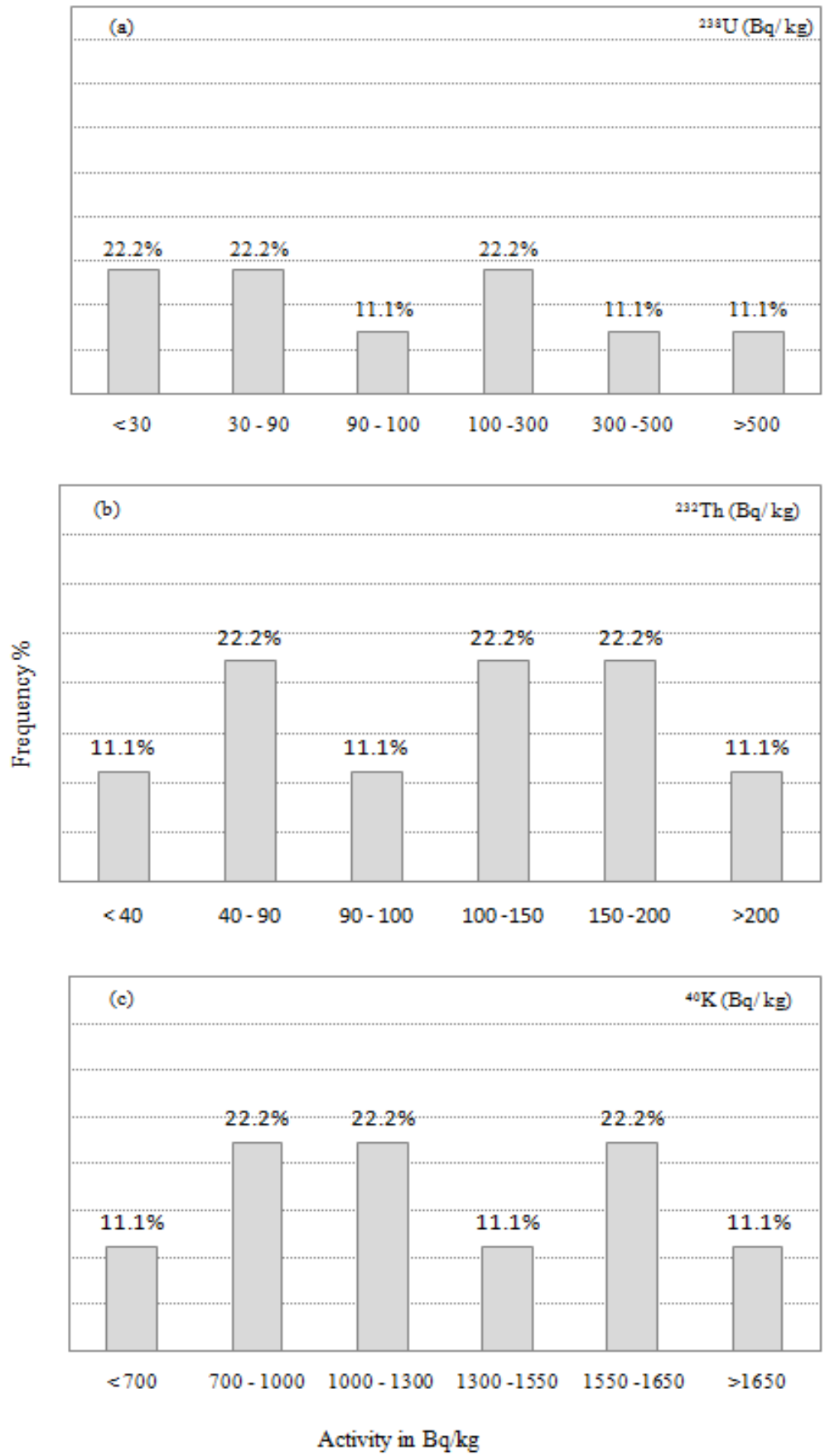

Figure 3. Frequency distributions of activity concentrations $\left(\mathrm{Bq} \mathrm{kg}^{-1}\right)$ for the Sol Hamed fine-grained granite: (a) ${ }^{238} \mathrm{U}$; (b) ${ }^{232} \mathrm{Th}$; (c) ${ }^{40} \mathrm{~K}$. 

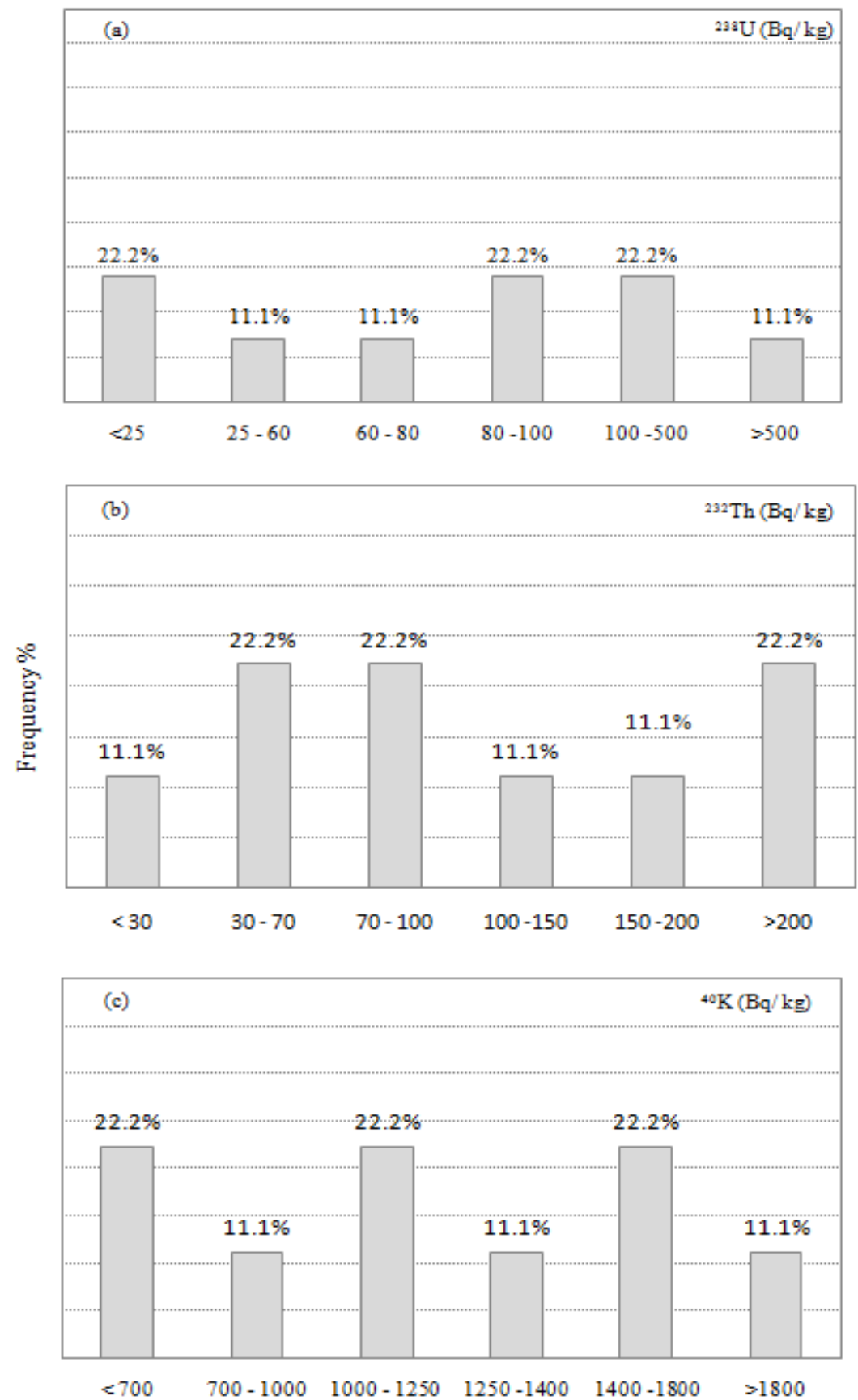

Activity in $\mathrm{Bq} / \mathrm{kg}$

Figure 4. Frequency distributions of activity concentrations $\left(\mathrm{Bq} \mathrm{kg}^{-1}\right)$ for the Sol Hamed coarsegrained granite: (a) ${ }^{238} \mathrm{U}$; (b) ${ }^{232} \mathrm{Th}$; (c) ${ }^{40} \mathrm{~K}$. 

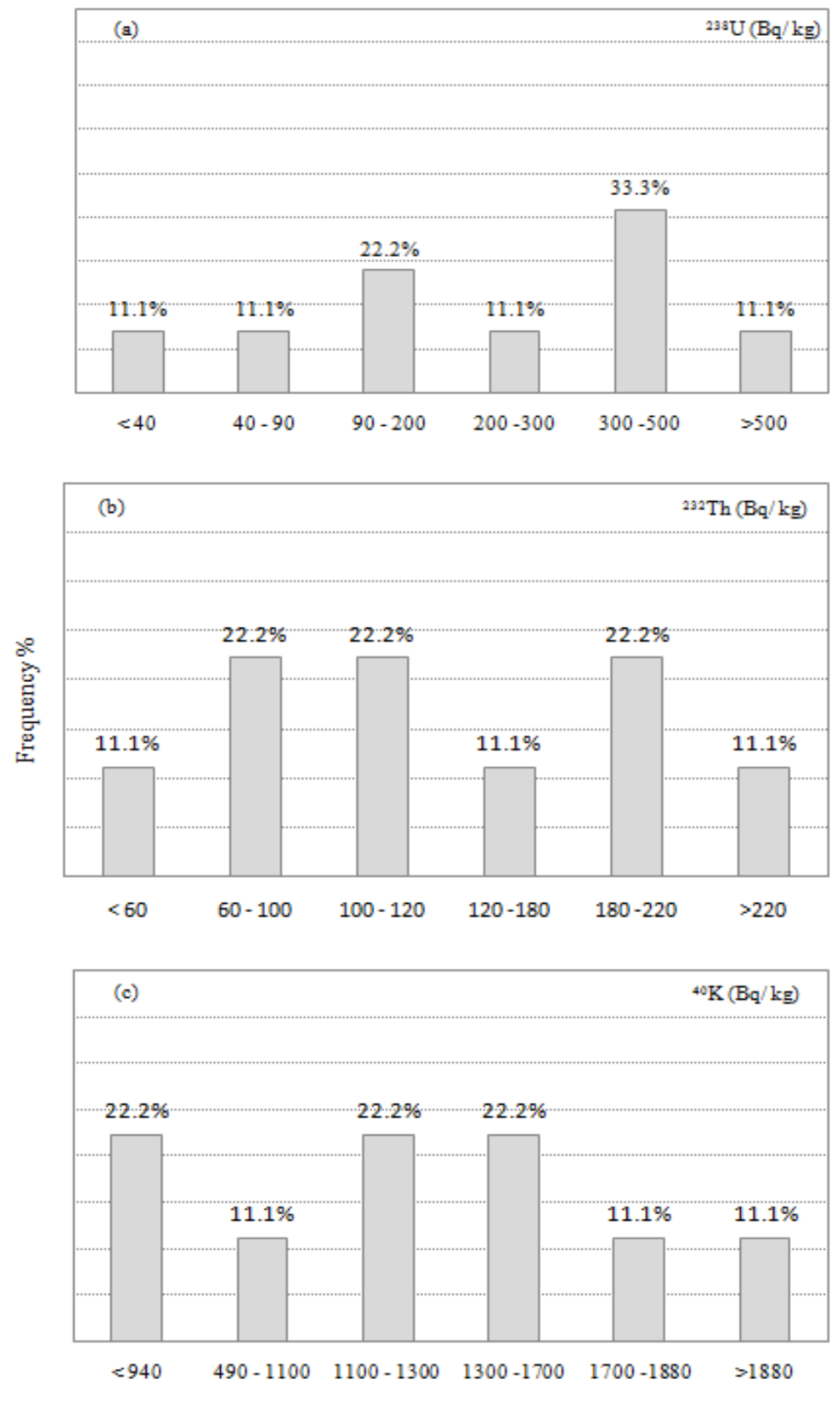

Activity in $\mathrm{Bq} / \mathrm{kg}$

Figure 5. Frequency distribution of activity concentrations $\left(\mathrm{Bq} \mathrm{kg}^{-1}\right)$ for the Sol Hamed bostonite dykes: (a) ${ }^{238} \mathrm{U}$; (b) ${ }^{232} \mathrm{Th}$; (c) ${ }^{40} \mathrm{~K}$. 

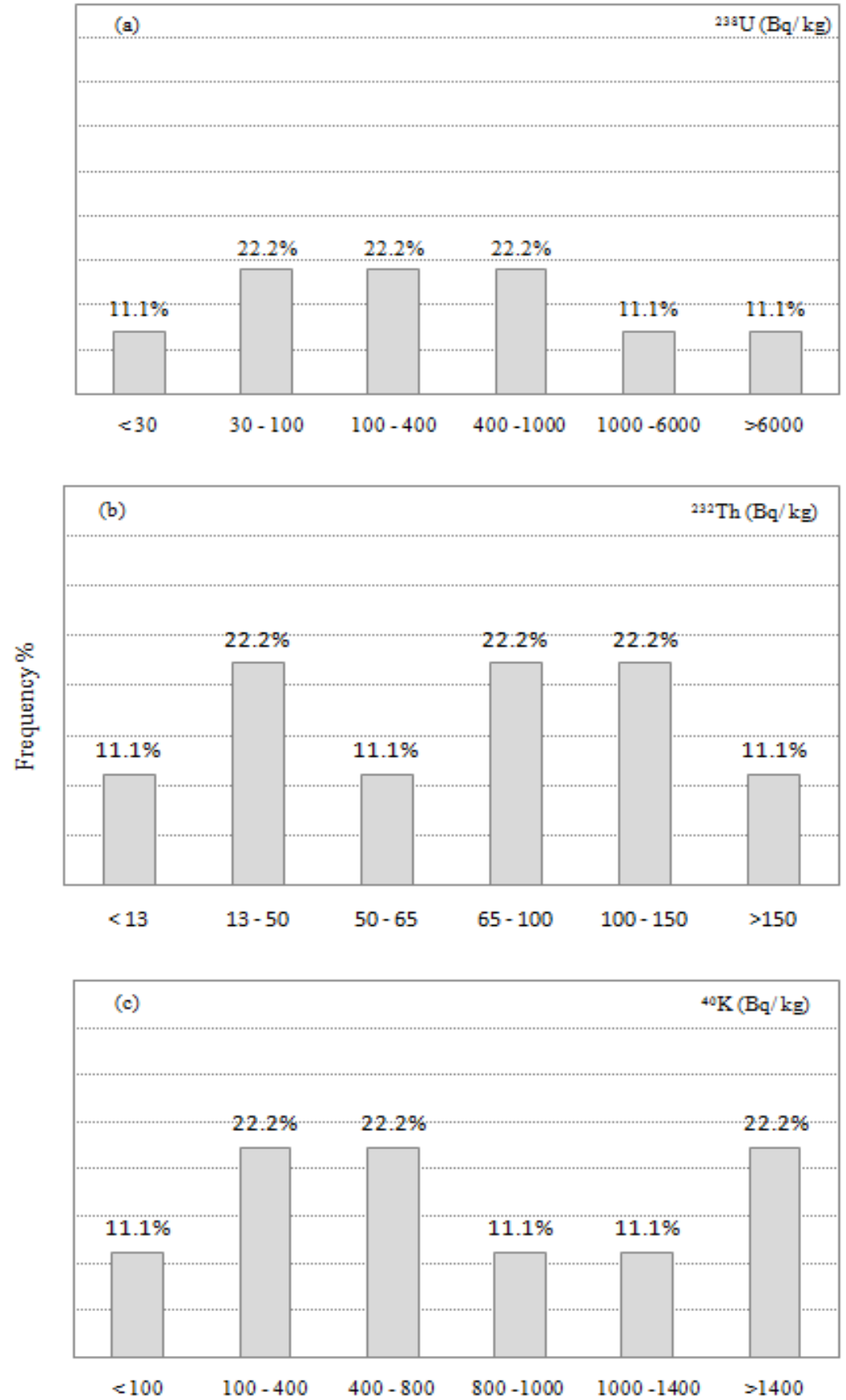

Activity in $\mathrm{Bq} / \mathrm{kg}$

Figure 6. Frequency distribution of activity concentrations $\left(\mathrm{Bq} \mathrm{kg}^{-1}\right)$ for the Sol Hamed lamprophyre dykes: (a) ${ }^{238} \mathrm{U}$; (b) ${ }^{232} \mathrm{Th}$; (c) ${ }^{40} \mathrm{~K}$.

\subsection{Geochemistry of $U$ and $T h$ in the Studied Rocks}

The relationships between the natural radionuclides $(\mathrm{U}$, Th, and $\mathrm{K})$ of the rocks tested were computed (Table 2), and are diagrammatically shown in Figures 7 and 8. 

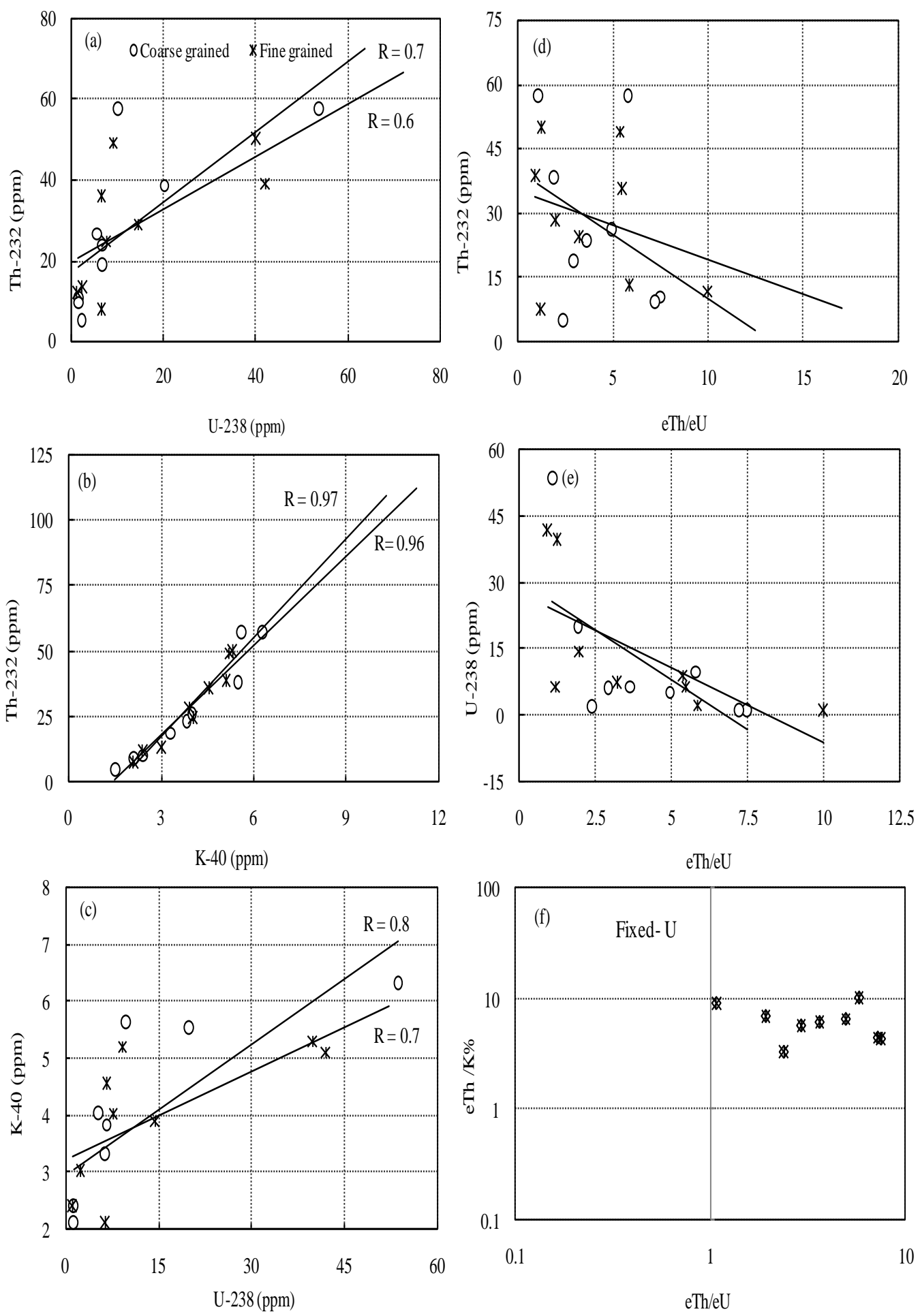

Figure 7. (a) Th vs. U, (b) Th vs. K, (c) K vs. U, (d) eTh vs. eTh/eU, (e) eU vs. eTh/eU, and (f) $\mathrm{eTh} / \mathrm{K} \%$ vs. eTh/eU for coarse-grained and fine-grained granites of the Sol Hamed area. 

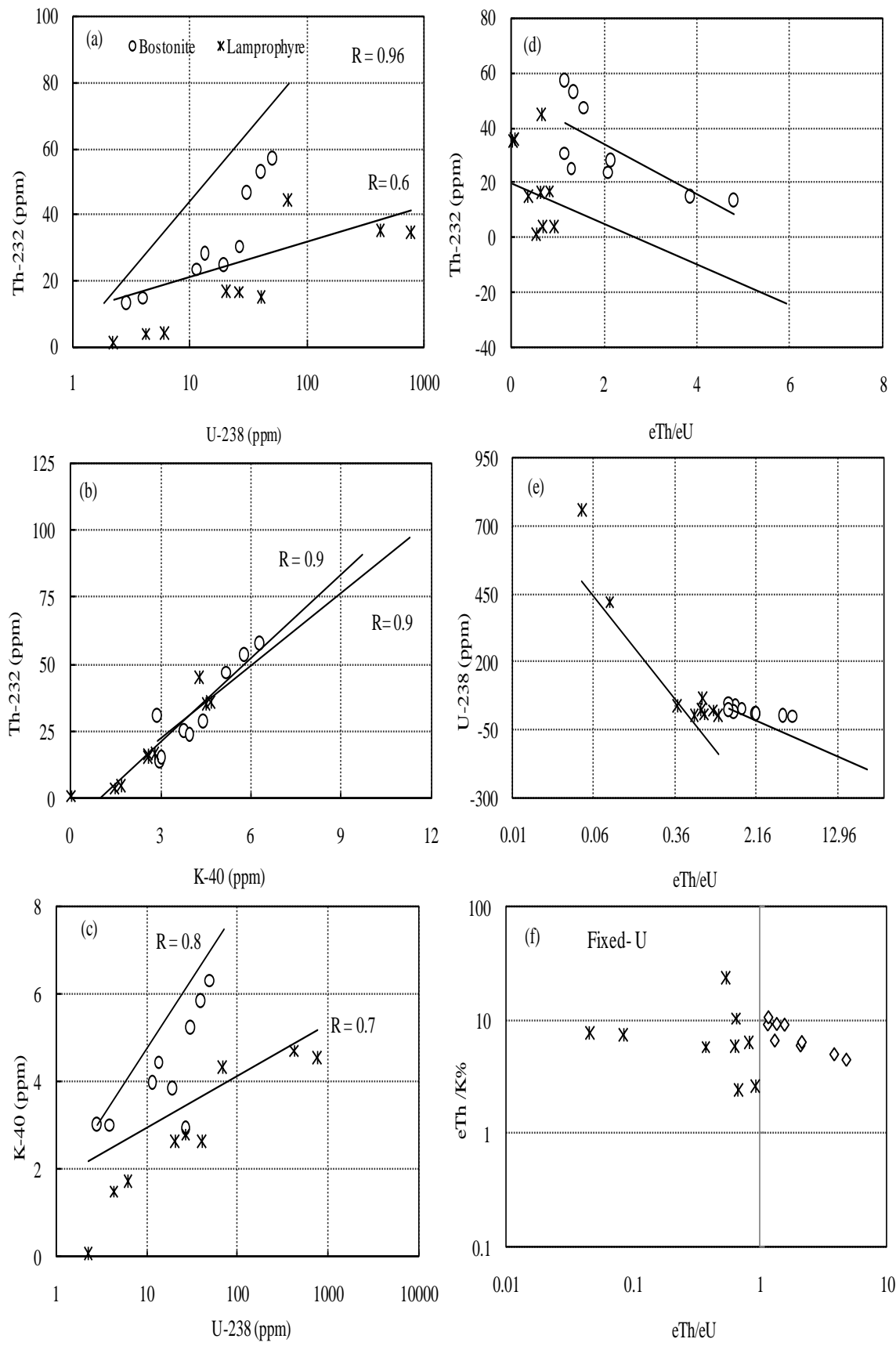

Figure 8. (a) Th vs. U, (b) Th vs. K, (c) K vs. U, (d) eTh vs. eTh/eU, (e) eU vs. eTh/eU, and (f) $\mathrm{eTh} / \mathrm{K} \%$ vs. eTh/eU for bostonite and lamprophyre granites of the Sol Hamed area.

Positive correlations between Th and $\mathrm{U}$ were observed for coarse-grained granite, fine-grained granite, bostonite, and lamprophyre $(R=0.7,0.6,0.9$, and 0.6 , respectively), suggesting magmatic processes exerted a significant influence on radioelement concentration (Figures $7 \mathrm{a}$ and $8 \mathrm{a}$ ).

Figures $5 \mathrm{~b}$ and $6 \mathrm{~b}$ illustrate that there was a strong positive correlation between Th and $\mathrm{K}$ $(R=0.96,0.97,0.9$, and 0.9$)$, and between $U$ and $K(R=0.8,0.7,0.8$, and 0.7$)$ for coarse-grained granite, fine-grained granite, bostonite, and lamprophyre, respectively (Figures 6 and 7 ).

The variations in Th and $U$ in the Th/ $U$ ratio showed a negative correlation for all samples tested, as illustrated in Figure 7d,e and Figure 8d,e. This result confirmed the concept that magmatic processes at least partly governed the radioactive element distribution in these rocks. 
The average value of the Th/U ratio for coarse-grained granite (4.2) and fine-grained granite (3.9) was greater than the Clark value (3.5), demonstrating that the radioelements in the investigated rocks were not extensively fractionated during weathering or implicated in the metasomatic activity [22].

On the other hand, the average value of the Th/U ratio for bostonite (2.2) and lamprophyre (0.5) was less than 3.5 (Clark value), which denoted enrichment of uranium and implicated reducing conditions. This result was confirmed by the average values of remobilization parameters of 12.3 and 144.3 for these rocks, respectively.

The cross plot of eTh/eU and eTh/K ratios presented in Figures $7 \mathrm{f}$ and $8 \mathrm{f}$ displays that these samples were found in the fixed-U and leached-U sectors. The average values for $\mathrm{eTh} / \mathrm{K}$ of $6.3,6.8,7.4$, and 8.1 were $>2 \times 10^{-4}$ for coarse-grained granite, fine-grained granite, bostonite, and lamprophyre, respectively. These values denoted thorium enrichment in the studied rocks.

\subsection{Radioactive Concentrations in Granitic Rocks}

Table 3 shows the activity concentrations of radionuclides ${ }^{238} \mathrm{U},{ }^{232} \mathrm{Th}$, and ${ }^{40} \mathrm{~K}$ in the examined granitic rocks (CG, FG, B, and L). The range (mean $\pm \mathrm{SD}$ ) of ${ }^{238} \mathrm{U},{ }^{232} \mathrm{Th}$, and ${ }^{40} \mathrm{~K}$ activity concentrations in the granitic rocks were 14-9386 (610 \pm 1730$), 5-233$ $(110 \pm 69)$, and 31-1971 (1157 \pm 467$) \mathrm{Bq} \mathrm{kg}^{-1}$, respectively. Natural radioactivity levels varied widely due to variations in activity concentration values for ${ }^{238} \mathrm{U},{ }^{232} \mathrm{Th}$, and ${ }^{40} \mathrm{~K}$ in geological formations and their physical, chemical, and geochemical characteristics [23]. The findings showed that the mean values of ${ }^{232} \mathrm{Th}$ and ${ }^{40} \mathrm{~K}$ were three times higher than the global averages of 45 and $412 \mathrm{~Bq} \mathrm{~kg}^{-1}$, respectively. Nonetheless, the mean uranium value was much greater than the global value of $33 \mathrm{~Bq} \mathrm{~kg}^{-1}$. The presence of uranium and thorium in the chemical components of heavy minerals (including zircon, fluorite, and apatite) and some other minerals (notably uraninite, thorianite, and monazite) that were found in granitic rocks could explain the increasing levels of radioactivity [12,24]. An analysis using descriptive statistics (skewness, kurtosis, and coefficient of variation (CV)) is also included in Table 3. According to a statistical study of radionuclides in granitic rock (GR), the skewness factor was used to illustrate the asymmetric distribution. The asymmetric nature was described by positive skewness values for ${ }^{238} \mathrm{U}$ and ${ }^{232} \mathrm{Th}$, while negative values of ${ }^{40} \mathrm{~K}$ described the flatness of its probability distributions. The kurtosis factor also revealed the probability peak of a distribution. As a result, the probability distributions for ${ }^{238} \mathrm{U},{ }^{232} \mathrm{Th}$, and ${ }^{40} \mathrm{~K}$ peaked when positive values were used. For ${ }^{238} \mathrm{U}$, ${ }^{232} \mathrm{Th}$, and ${ }^{40} \mathrm{~K}$, the projected coefficient of variation $(\mathrm{CV})$ values were high, with values of $93 \%, 99 \%$, and $248 \%$, respectively. This was corroborated by the presence of several radioelement-bearing minerals in the examined GR.

Figure 9a-c show the frequency distributions of ${ }^{238} \mathrm{U},{ }^{232} \mathrm{Th}$, and ${ }^{40} \mathrm{~K}$ activity concentrations in all the examined GR. Table 4 displays the normal distribution predicted for ${ }^{232} \mathrm{Th}$ and ${ }^{40} \mathrm{~K}$ activity concentrations in the GR, while multimodality distribution was perceived for ${ }^{238} \mathrm{U}$ activity concentration. 

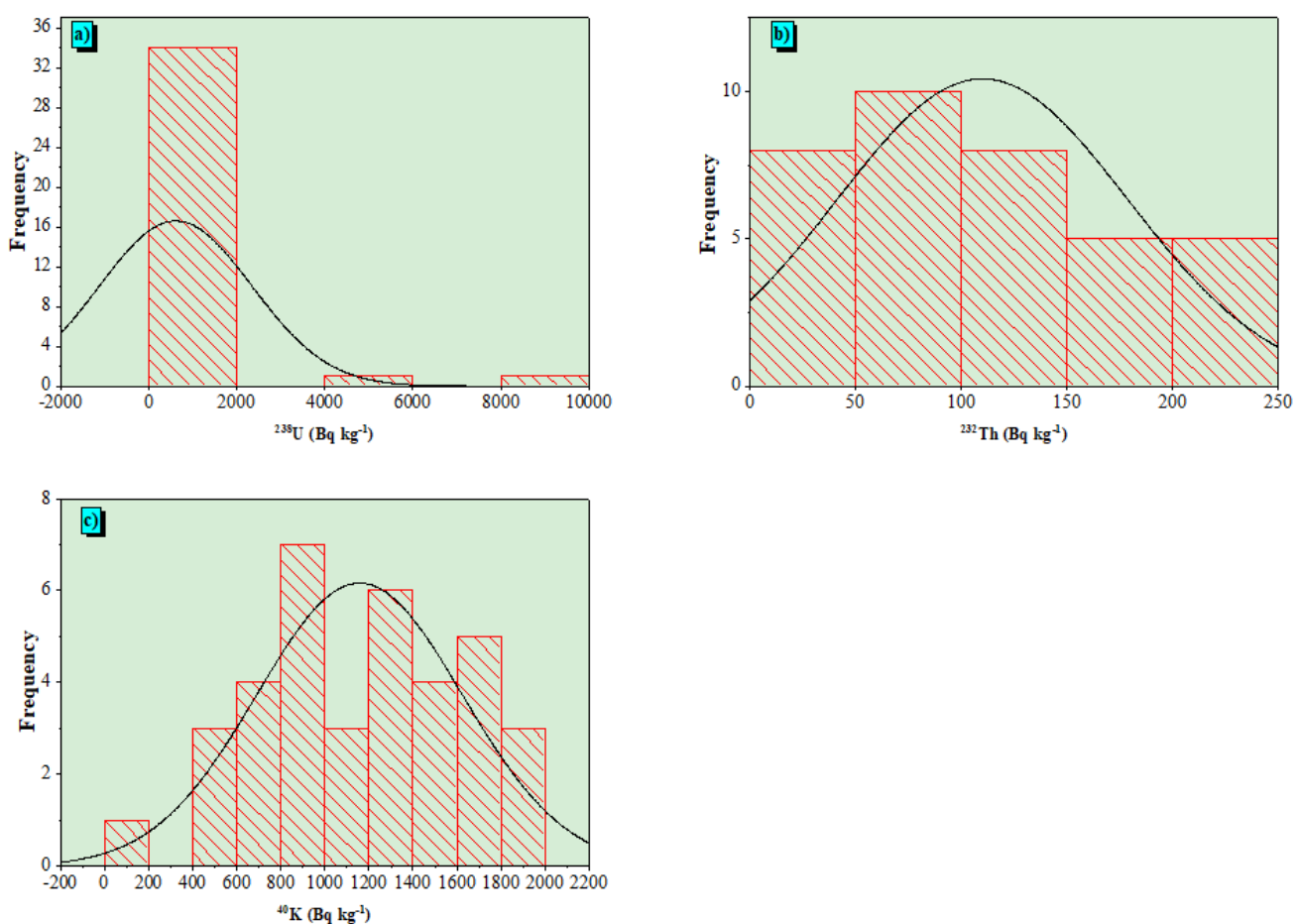

Figure 9. The frequency distribution of: (a) ${ }^{238} \mathrm{U}$ activity concentration, (b) ${ }^{232} \mathrm{Th}$ activity concentration, and (c) ${ }^{40} \mathrm{~K}$ activity concentration in the GR in the studied area.

Table 3. Descriptive statistics of ${ }^{238} \mathrm{U},{ }^{232} \mathrm{Th}$, and ${ }^{40} \mathrm{~K}$ activity concentrations of the studied granitic rock.

\begin{tabular}{|c|c|c|c|c|c|c|c|c|}
\hline Radionuclides & $\mathbf{N}^{*}$ & $\begin{array}{c}\text { Mean } \\
\text { Bq kg }^{-1}\end{array}$ & $\begin{array}{c}\mathrm{SD}^{* *} \\
\mathrm{~Bq} \mathrm{~kg}^{-1}\end{array}$ & $\underset{\mathrm{Bq} \mathrm{kg}^{-1}}{\operatorname{Min}}$ & $\underset{\text { Bq kg }^{-1}}{\operatorname{Max}}$ & Skewness & Kurtosis & $\mathrm{CV}, \%$ \\
\hline \multicolumn{9}{|c|}{ Coarse-grained (CG) } \\
\hline${ }^{238} \mathrm{U}$ & 9 & 146 & 206 & 16 & 662 & 2.4 & 6.1 & 141 \\
\hline${ }^{232} \mathrm{Th}$ & 9 & 111 & 80 & 20 & 233 & 0.7 & -0.9 & 72 \\
\hline${ }^{40} \mathrm{~K}$ & 9 & 1199 & 528 & 469 & 1971 & 0.1 & -1.4 & 44 \\
\hline \multicolumn{9}{|c|}{ Fine-grained (FG) } \\
\hline${ }^{238} \mathrm{U}$ & 9 & 178 & 192 & 14 & 519 & 1.4 & 0.3 & 108 \\
\hline${ }^{232} \mathrm{Th}$ & 9 & 117 & 64 & 31 & 203 & 0.0 & -1.5 & 55 \\
\hline${ }^{40} \mathrm{~K}$ & 9 & 1234 & 379 & 657 & 1658 & -0.4 & -1.4 & 31 \\
\hline \multicolumn{9}{|c|}{ Bostonite (B) } \\
\hline${ }^{238} \mathrm{U}$ & 9 & 267 & 196 & 34 & 611 & 0.5 & -0.6 & 74 \\
\hline${ }^{232} \mathrm{Th}$ & 9 & 132 & 65 & 54 & 233 & 0.5 & -1.3 & 50 \\
\hline${ }^{40} \mathrm{~K}$ & 9 & 1332 & 396 & 907 & 1971 & 0.5 & -1.2 & 30 \\
\hline \multicolumn{9}{|c|}{ Lamprophyre (L) } \\
\hline${ }^{238} \mathrm{U}$ & 9 & 1849 & 3267 & 27 & 9386 & 2.0 & 3.4 & 177 \\
\hline${ }^{232} \mathrm{Th}$ & 9 & 78 & 63 & 5 & 181 & 0.5 & -1.2 & 82 \\
\hline${ }^{40} \mathrm{~K}$ & 9 & 862 & 482 & 31 & 1471 & -0.2 & -0.6 & 56 \\
\hline \multicolumn{9}{|c|}{$\mathrm{GR}+\mathrm{L}$} \\
\hline${ }^{238} \mathrm{U}$ & 36 & 610 & 1730 & 14 & 9386 & 4.5 & 20.8 & 284 \\
\hline${ }^{232} \mathrm{Th}$ & 36 & 110 & 69 & 5 & 233 & 0.4 & -1.0 & 63 \\
\hline${ }^{40} \mathrm{~K}$ & 36 & 1157 & 467 & 31 & 1971 & -0.2 & -0.5 & 40 \\
\hline
\end{tabular}

${ }^{*} \mathrm{~N}=$ the number of samples, ${ }^{* *} \mathrm{SD}=$ standard deviation.

Table 4. Results of normality tests.

\begin{tabular}{cccc}
\hline Radionuclide & \multicolumn{2}{c}{ Kolmogorov-Smirnov } \\
& DF & Statistic & $p$-Value \\
\hline${ }^{238} \mathrm{U}$ & 36 & 0.40 & $7.7 \times 10^{-6}$ \\
${ }^{232} \mathrm{Th}$ & 36 & 0.12 & 0.70 \\
${ }^{40} \mathrm{~K}$ & 36 & 0.10 & 0.96 \\
\hline
\end{tabular}

Asymp. sig. $=$ asymptotic significance level; $\mathrm{DF}=$ degrees of freedom. ${ }^{*}$ Lilliefors significance correction. 
The obtained data on ${ }^{238} \mathrm{U},{ }^{232} \mathrm{Th}$, and ${ }^{40} \mathrm{~K}$ activity in the current study were compared to those found in previous studies conducted in other countries (Table 5). The comparison showed that the concentrations of ${ }^{238} \mathrm{U},{ }^{232} \mathrm{Th}$, and ${ }^{40} \mathrm{~K}$ activity were affected by the geological characteristics of the analyzed locations.

Table 5. A comparison between the activity concentration of radionuclides presented in studied granitic rock and other areas.

\begin{tabular}{ccccc}
\hline Country & ${ }^{238} \mathbf{U}$ & ${ }^{232} \mathbf{T h}$ & ${ }^{40} \mathbf{K}$ & References \\
\hline Egypt & $610.3 \pm 1730.9$ & $109.9 \pm 68.9$ & $1157.2 \pm 466.8$ & Present study \\
Palestine & 71 & 82 & 780 & {$[25]$} \\
Saudi Arabia & 28.82 & 34.83 & 665.08 & {$[26]$} \\
Spain & 84 & 42 & 1138 & {$[27]$} \\
India & 25.88 & 42.82 & 560.6 & {$[28]$} \\
Iran & $77.4 \pm 21$ & $44.5 \pm 12$ & $1017.2 \pm 154$ & {$[29]$} \\
Turkey & $80 \pm 11$ & $101 \pm 17$ & $974 \pm 102$ & {$[30]$} \\
Nigeria & $63.29 \pm 13.87$ & $226.67 \pm 28.05$ & $832.59 \pm 241.53$ & {$[2]$} \\
Egypt & $2989 \pm 2757$ & $460 \pm 311$ & $1073 \pm 560$ & {$[10]$} \\
Jordan & $41.52 \pm 3.23$ & $58.42 \pm 0.44$ & $897 \pm 43$ & {$[31]$} \\
Greek & $74 \pm 51$ & $85 \pm 54$ & $881 \pm 331$ & {$[18]$} \\
Egypt & 137 & 82 & 1082 & {$[32]$} \\
\hline
\end{tabular}

\subsection{Radiological Effects}

The computed radium equivalent $\left(\mathrm{Ra}_{\mathrm{eq}}\right)$ values for granitic rock (GR) of the Sol Hamed area altered between 36 and $9697 \mathrm{~Bq} \mathrm{~kg}^{-1}$, with a mean value of $856 \pm 1762 \mathrm{~Bq} \mathrm{~kg}^{-1}$. The $\left(\mathrm{Ra}_{\mathrm{eq}}\right)$ values were higher than the global approved permissible limit of $370 \mathrm{~Bq} \mathrm{~kg}^{-1}$ [33]; this is an acceptable limitation that does not preserve the external dose under $1.5 \mathrm{mSv} / \mathrm{y}$ [4].

The mean value of $\left(\mathrm{H}_{\mathrm{in}}\right)$ for GR samples was $3.9 \pm 9.4$. The range $\left(\mathrm{H}_{\mathrm{in}}\right)$ values ranged from 0.17 to 51.5 in the GR of the Sol Hamed area. The external hazard index $\left(\mathrm{H}_{\mathrm{ex}}\right)$ values for GR samples ranged from 0.09 to 26 , with a mean value of $2.3 \pm 4.7$. The $\left(\mathrm{H}_{\mathrm{in}}\right)$ and $\left(\mathrm{H}_{\mathrm{ex}}\right)$ mean values in all measured GR samples in the studied area demonstrated overexposure; i.e., those values were found to be higher than the approved limit $(<1)$ [34] (Figure 10).

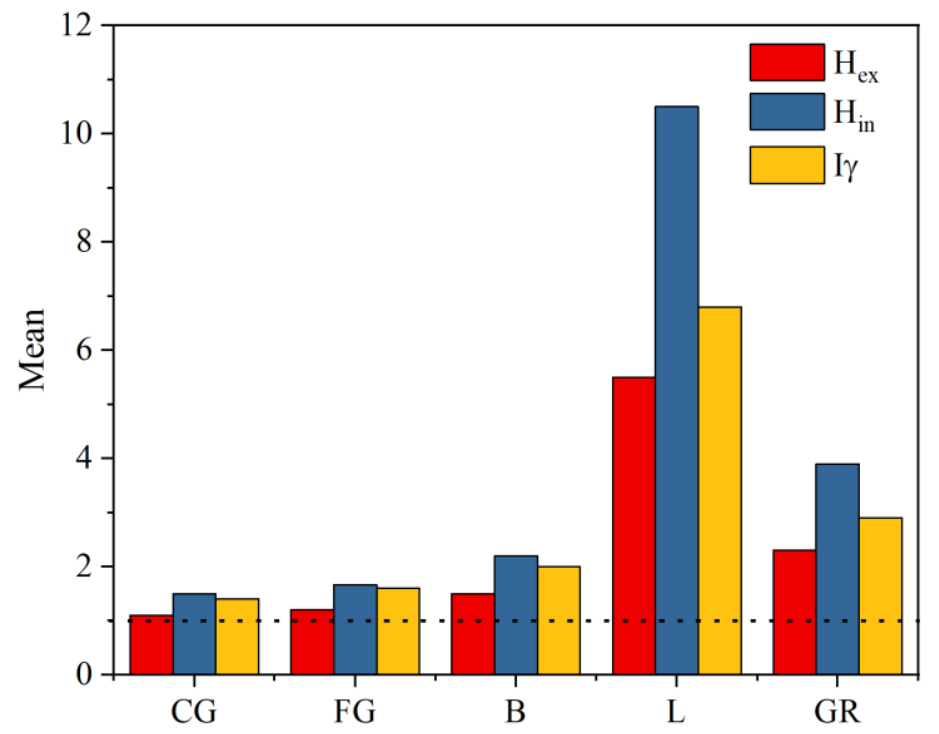

Figure 10. Mean values of the external $\left(\mathrm{H}_{\mathrm{ex}}\right)$ and internal $\left(\mathrm{H}_{\mathrm{in}}\right)$ hazard indices and representative gamma index $(\mathrm{I} \gamma)$ of GR at the Sol Hamed area, Egypt.

The $\left(\mathrm{I}_{\gamma}\right)$ for GR samples had a mean value of $2.9 \pm 5.8$, with lowest and highest values of 0.12 and 32.4, respectively. The mean values were lower than the permissible limit $<1$ 
(Figure 10) [35]. The values of I $\gamma$ illustrated that the GR samples in the Sol Hamed area pose a significant health risk, and are not candidates to be employed as construction materials.

The GR's obtained $\left(D_{\text {air }}\right)$ values were greater than the recommended mean worldwide value of $59 \mathrm{nGy} / \mathrm{h}$ [4]. The ( $\left.\mathrm{D}_{\text {air }}\right)$ values for samples of GR ranged from 16.7 to $4479 \mathrm{nGy} \mathrm{h}^{-1}$, with a mean value of $396 \pm 814 \mathrm{nGy} \mathrm{h}^{-1}$. This showed that the GR of the Sol Hamed area is not suitable to apply in several infrastructure applications, particularly in building materials.

The $\left(\mathrm{AED}_{\text {out }}\right)$ values fluctuated from 0.02 to $5.4 \mathrm{mSv}^{-1}$, with a mean value of $0.48 \mathrm{mSv}^{-1}$ for the GR samples at the Sol Hamed area (Table 6), which were greater than the approved worldwide mean of $0.07 \mathrm{mSv} \mathrm{y}^{-1}$ [4].

Table 6. Results of different hazard indices associated with the radioactivity of granitic rocks at Sol Hamed, Southeastern Desert, Egypt.

\begin{tabular}{|c|c|c|c|c|c|c|c|c|c|c|}
\hline Granites & $\begin{array}{l}\text { (Statistical } \\
\text { parameter) }\end{array}$ & $\mathrm{Ra}_{\mathrm{eq}}$ & $\mathbf{H}_{\text {in }}$ & $\mathrm{H}_{\mathrm{ex}}$ & $\mathbf{I} \gamma$ & $\mathrm{D}_{\text {air }}$ & AED $_{\text {out }}$ & $\mathrm{AED}_{\text {in }}$ & AGDE & $\begin{array}{l}\text { ELCR } \\
\times 10^{-3} \\
\end{array}$ \\
\hline \multirow[t]{2}{*}{ CG } & Range & $91-1148$ & $0.3-4.9$ & $0.25-3.1$ & $0.3-4.0$ & $43.5-528$ & $0.05-0.64$ & $0.21-2.5$ & $0.31-3.6$ & $0.18-2.27$ \\
\hline & Mean $\stackrel{ \pm}{ \pm}$ SD & $398 \pm 337$ & $1.5 \pm 1.4$ & $1.1 \pm 0.9$ & $1.4 \pm 1.2$ & $184 \pm 154$ & $0.23 \pm 0.18$ & $0.9 \pm 0.7$ & $1.29 \pm 1.0$ & $0.8 \pm 0.6$ \\
\hline \multirow[t]{2}{*}{ FG } & Range & $142-913$ & $0.4-3.8$ & $0.3-2.4$ & $0.5-3.2$ & $67-419$ & $0.08-0.5$ & $0.32-2.05$ & $0.48-2.89$ & $0.28-1.8$ \\
\hline & Mean $\stackrel{ \pm}{ \pm}$ SD & $441 \pm 285$ & $1.67 \pm 1.2$ & $1.2 \pm 0.7$ & $1.6 \pm 0.9$ & $204 \pm 131$ & $0.25 \pm 0.16$ & $1.0 \pm 0.64$ & $1.4 \pm 0.8$ & $0.87 \pm 0.56$ \\
\hline \multirow[t]{2}{*}{ B } & Range & 184-1096 & $0.6-4.6$ & $0.5-2.9$ & $0.7-3.8$ & $87-504$ & $0.1-0.6$ & $0.4-2.5$ & $0.6-3.5$ & $0.37-2.1$ \\
\hline & Mean $\stackrel{ \pm}{ \pm}$ SD & $559 \pm 315$ & $2.2 \pm 1.4$ & $1.5 \pm 0.8$ & $2.0 \pm 1.0$ & $258 \pm 143$ & $0.3 \pm 0.17$ & $1.26 \pm 0.7$ & $1.8 \pm 0.9$ & $1.1 \pm 0.62$ \\
\hline \multirow[t]{2}{*}{$\mathrm{L}$} & Range & $36-9697$ & $0.17-51.5$ & $0.09-26$ & $0.12-32.4$ & $16.7-4479$ & $0.02-5.4$ & $0.08-22$ & $0.11-30$ & $0.07-1.9$ \\
\hline & Mean \pm SD & $2027 \pm 3349$ & $10.5 \pm 17.8$ & $5.5 \pm 9.0$ & $6.8 \pm 11.1$ & $936 \pm 1546$ & $1.1 \pm 1.8$ & $4.5 \pm 7.5$ & $6.3 \pm 10.3$ & $4 \pm 6$ \\
\hline \multirow[t]{2}{*}{ GR } & Range & $36-9697$ & $0.17-51.5$ & $0.09-26$ & $0.12-32.4$ & $16.7-4479$ & $0.02-5.4$ & $0.08-22$ & $0.11-30$ & $0.07-19$ \\
\hline & Mean \pm SD & $856 \pm 1762$ & $3.9 \pm 9.4$ & $2.3 \pm 4.7$ & $2.9 \pm 5.8$ & $396 \pm 814$ & $0.48 \pm 0.99$ & $1.9 \pm 3.9$ & $2.7 \pm 15.4$ & $1.7 \pm 3.4$ \\
\hline
\end{tabular}

The $\left(\mathrm{AED}_{\mathrm{in}}\right)$ varied from 0.08 to $22 \mathrm{mSv} \mathrm{y}^{-1}$, with a mean value of $1.9 \mathrm{mSv} \mathrm{y}^{-1}$ for the GR samples. The mean values for $\left(\mathrm{AED}_{\mathrm{in}}\right)$ were moderately higher than the worldwide recommended limit of $0.41 \mathrm{mSv} \mathrm{y}^{-1}$ [4]. The high doses can be ascribed to heavy minerals such as monazite, uraninite, and thorianite, which were concentrated in the granites. Furthermore, exposure to high doses for a long period can affect unfavorable health impacts such as cancer, and cardiovascular diseases have been linked to tissue degeneration and deoxyribonucleic acid (DNA) in genes [36].

The AGDE values ranged between 0.11 and $30 \mathrm{mSv} \mathrm{y}^{-1}$. The mean value was $2.7 \pm 15.4 \mathrm{mSv} \mathrm{y}^{-1}$, which was nine times higher than the allowable limit of $0.3 \mathrm{mSv} \mathrm{y}^{-1}$ [4]. Therefore, the granitic rock in the Sol Hamed area is not safe to use in construction materials.

The (ELCR) values ranged from $0.07 \times 10^{-3}$ to $19 \times 10^{-3}$, with a mean value of $1.7 \times 10^{-3}$ for the GR samples, which agreed with the approved value [37] (Table 6). This suggested that exposure to the gamma rays released by the examined granitic may have adverse health effects on humans over the course of their lives.

\subsection{Multivariate Statistics}

A multivariate statistical approach was used to determine the associations and relationships between activity concentrations and the related potential radiological hazard factors. This work used statistics analysis such as Pearson correlation, principal component analysis (PCA), and hierarchical cluster analysis (HCA).

Table 7 shows the Pearson correlation of radioactive parameters in the Sol Hamed area. The corresponding potential radiological hazard parameters had a very strong correlation with ${ }^{238} \mathrm{U}$. While the ${ }^{238} \mathrm{U}$ showed a weak correlation with the ${ }^{40} \mathrm{~K}$ activity, concentrations as an isotope did not decay from the radioactive natural series. Moreover, there was a very strong correlation between the ${ }^{232} \mathrm{Th}$ and ${ }^{40} \mathrm{~K}(0.95)$. Thus, radiological dangers and health risks are caused by high uranium activity concentrations in GR. 
Table 7. The concentrations of radionuclides ${ }^{238} \mathrm{U},{ }^{232} \mathrm{Th},{ }^{40} \mathrm{~K}$ and the radiological hazard indices.

\begin{tabular}{|c|c|c|c|c|c|c|c|c|c|c|c|c|}
\hline & ${ }^{238} \mathrm{U}$ & ${ }^{232} \mathrm{Th}$ & ${ }^{40} \mathrm{~K}$ & $\mathrm{Ra}_{\mathrm{eq}}$ & $\mathbf{H}_{\mathrm{in}}$ & $\mathbf{H}_{\mathrm{ex}}$ & $\mathrm{I} \gamma$ & $\mathrm{D}_{\text {air }}$ & $\mathrm{AED}_{\text {out }}$ & $\mathrm{AED}_{\text {in }}$ & AGDE & ELCR \\
\hline${ }^{238} \mathrm{U}$ & 1 & & & & & & & & & & & \\
\hline${ }^{232} \mathrm{Th}$ & 0.19 & 1 & & & & & & & & & & \\
\hline${ }^{40} \mathrm{~K}$ & 0.21 & 0.95 & 1 & & & & & & & & & \\
\hline $\mathrm{Ra}_{\mathrm{eq}}$ & 1.00 & 0.26 & 0.28 & 1 & & & & & & & & \\
\hline $\mathrm{H}_{\text {in }}$ & 1.00 & 0.23 & 0.24 & 0.99 & 1 & & & & & & & \\
\hline $\mathrm{H}_{\mathrm{ex}}$ & 1.00 & 0.26 & 0.28 & 1 & 0.99 & 1 & & & & & & \\
\hline $\mathrm{I} \gamma$ & 1.00 & 0.27 & 0.29 & 0.99 & 0.99 & 0.99 & 1 & & & & & \\
\hline $\mathrm{D}_{\text {air }}$ & 1.00 & 0.26 & 0.28 & 1 & 0.99 & 0.99 & 0.99 & 1 & & & & \\
\hline $\mathrm{AED}_{\text {out }}$ & 1.00 & 0.26 & 0.28 & 1 & 0.99 & 0.99 & 0.99 & 1 & 1 & & & \\
\hline AED & 1.00 & 0.26 & 0.28 & 1 & 0.99 & 0.99 & 0.99 & 1 & 1 & 1 & & \\
\hline AGDE & 1.00 & 0.27 & 0.28 & 0.99 & 0.99 & 0.99 & 0.99 & 0.99 & 0.99 & 0.99 & 1 & \\
\hline ELCR & 1.00 & 0.26 & 0.28 & 1 & 0.99 & 0.99 & 0.99 & 1 & 1 & 1 & 0.99 & 1 \\
\hline
\end{tabular}

A principal component analysis reduces a large number of variables to a few different types of components. Within a multivariate data collection, the PCA results-processing approach aims to find any simple underlying structure. Loadings that illustrate the changeable's relevance to the elements are bolded for values greater than 0.7. Characterizing each item exposes a few high loadings and many near-zero loadings, allowing the rotation to achieve its objectives. Increasing the range of loadings, which drives to the extreme with negative, positive, or near-zero loadings, maximizes variance. A PCA was used in this study to examine the matrix correlations between several components using varimax rotations. Figure 11 displays the PC1 and PC2 components.

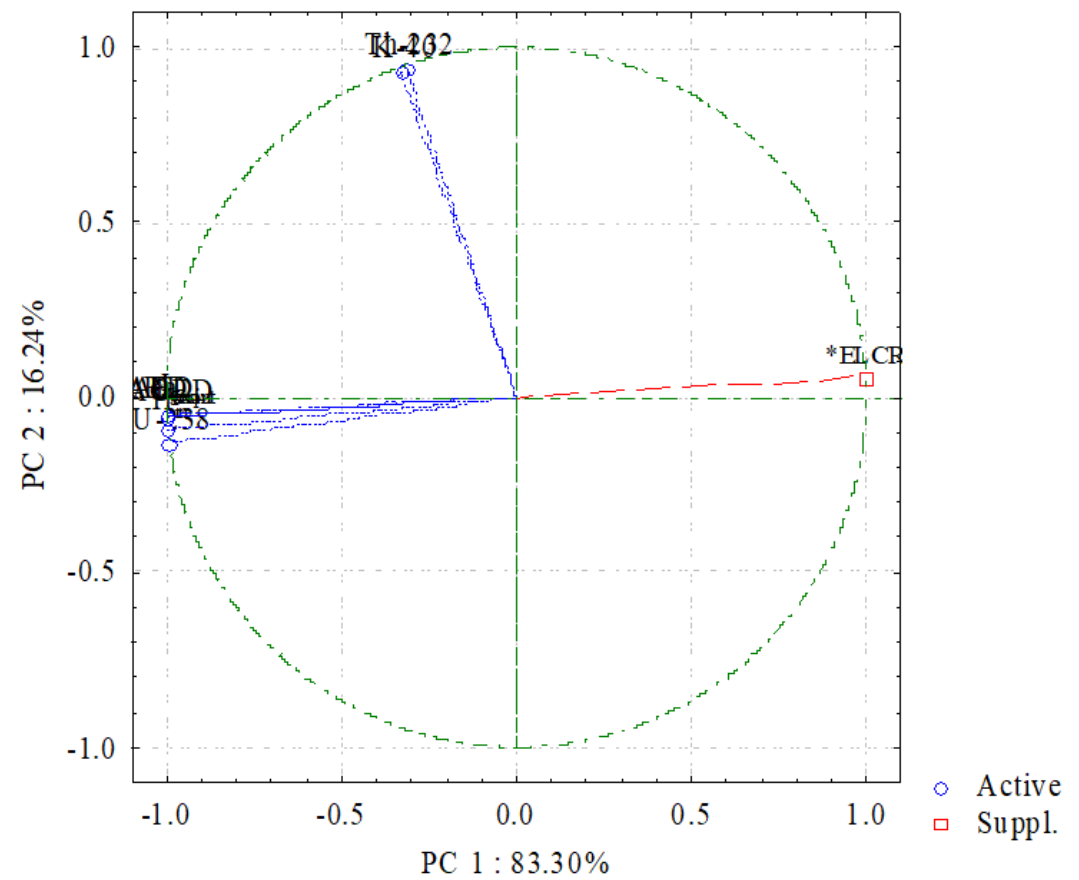

Figure 11. Principal component analysis (PC1 and PC2) of radiological data for GR at the Sol Hamed area.

The activity concentrations of ${ }^{238} \mathrm{U}$ and ${ }^{232} \mathrm{Th}$ in the GR samples showed a strong positive in PC1 loading, which was connected to all radiological variables, and $83.30 \%$ of the variation was explained (Figure 11). As a result, the most common natural radioactive contributions in the GR at the study location were ${ }^{238} \mathrm{U}$ activity concentrations. PC2 explained $16.24 \%$ of the variation [34]. 
A hierarchical clustering approach was used to analyze the data of radiological parameters. The link between all of the factors is depicted in Figure 12. There were two clusters in the dendrogram of the analyzed data in the GR of the Sol Hamed area. The ${ }^{238} U$ and radiological hazard factors made up Cluster I in the GR at the studied area. While Cluster II contained ${ }^{232} \mathrm{Th}$ and ${ }^{40} \mathrm{~K}$, which was linked to Cluster I, this investigation revealed that the total radioactivity in GR was due to uranium minerals. Finally, the results of the cluster analysis agreed with those of the Pearson correlation and PCA analysis.

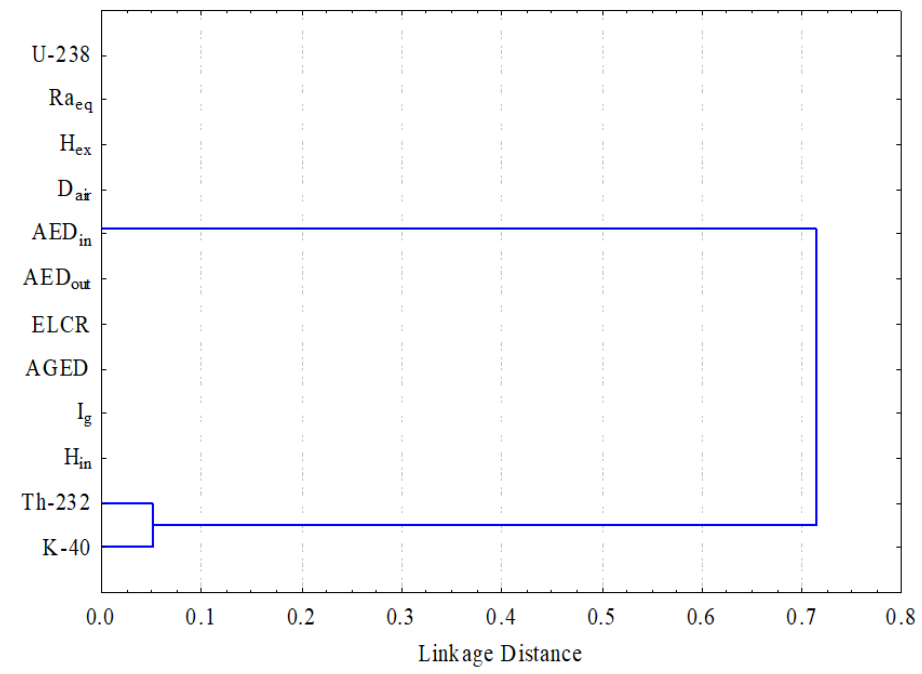

Figure 12. The clustering analysis of the radiological parameters of GR in the Sol Hamed area.

\section{Conclusions}

The current study examined the distribution and possible modes of natural radioactive elements in granitic samples from the Sol Hamed area of the Southeastern Desert of Egypt. The obtained data displayed ${ }^{238} \mathrm{U},{ }^{232} \mathrm{Th}$, and ${ }^{40} \mathrm{~K}$ activity concentrations of $610 \pm 1730$, $110 \pm 69$, and $1157 \pm 467 \mathrm{~Bq} \mathrm{~kg}^{-1}$, respectively, which were higher than the approved worldwide values of 33,45 , and $412 \mathrm{~Bq} \mathrm{~kg}^{-1}$, respectively. The radium equivalent content absorbed dose rate, annual effective dose external and internal hazard indices, and most other radiological hazard characteristics were assessed. Furthermore, the mean values of annual gonadal dosage equivalent $\left(2.7 \mathrm{mSv}^{-1}\right)$ and the increased lifetime cancer risk $\left(1.7 \times 10^{-3}\right)$ were calculated. Multivariate statistical approaches were applied and illustrated that the ${ }^{238} \mathrm{U}$ principally contributed to and was predominant in the radioactivity of the granitic rock. The granitic rock included radioactivity-bearing minerals such as zircon, monazite, uraninite, thoronite, etc. Thus, Sol Hamed granites are one of Egypt's greatest U favorability locations for holding $U$ mineralization and using the granitic rock in building supplies poses a health concern for the wider public.

Author Contributions: Conceptualization, M.G.E.-F., S.H.T. and S.M.E.M.; methodology, H.A.S. and O.A.E.; software, M.Y.H. validation, E.-A.H.A. and E.-S.Y.; formal analysis, M.G.E.-F. and M.Y.H.; investigation, M.G.E.-F., S.H.T. and S.M.E.M.; resources, H.A.S. and O.A.E.; data curation, M.G.E.-F. and M.Y.H.; writing —original draft preparation, S.H.T. and S.M.E.M. and M.Y.H.; writing-review and editing, M.G.E.-F., S.H.T. and M.Y.H.; visualization, H.A.S. and O.A.E.; supervision, E.-A.H.A. and M.G.E.-F.; project administration, S.M.E.M. and O.A.E.; funding acquisition, E.-S.Y. All authors have read and agreed to the published version of the manuscript.

Funding: This research project was funded by the Deanship of Scientific Research at King Khalid University (KKU) (no. RGP.1/213/42).

Acknowledgments: The authors extend their appreciation to the Deanship of Scientific Research at King Khalid University (KKU) for funding this research project.

Conflicts of Interest: The authors declare no conflict of interest. 


\section{References}

1. Hanfi, M.Y.; Yarmoshenko, V.; Seleznev, A.A.; Malinovsky, G.; Ilgasheva, E.; Zhukovsky, M.V. Beta radioactivity of urban surface-deposited sediment in three Russian cities. Environ. Sci. Pollut. Res. 2020, 27, 40309-40315. [CrossRef] [PubMed]

2. Akpanowo, M.A.; Umaru, I.; Iyakwari, S.; Joshua, E.O.; Yusuf, S.; Ekong, G.B. Determination of natural radioactivity levels and radiological hazards in environmental samples from artisanal mining sites of Anka, North-West Nigeria. Sci. African 2020, 10, e00561. [CrossRef]

3. Sivakumar, S.; Chandrasekaran, A.; Ravisankar, R.; Ravikumar, S.M.; Prince Prakash Jebakumar, J.; Vijayagopal, P.; Vijayalakshmi, I.; Jose, M.T. Measurement of natural radioactivity and evaluation of radiation hazards in coastal sediments of east coast of Tamilnadu using statistical approach. J. Taibah Univ. Sci. 2014, 8, 375-384. [CrossRef]

4. UNSCEAR. Sources and Effects of Ionizing Radiation-Exposures of the Public and Workers from Various Sources of Radiation-UNSCEAR 2008 Report; United Nations Publication: New York, NY, USA, 2010.

5. ATSDR. Toxicological Profile for Uranium; U.S. Department of Health \& Human Services: Washington, WA, USA, 1999; pp. 1-145.

6. ATSDR. Draft Toxicological Profile for Radon: Agency for Toxic Substances and Disease Registry; U.S. Department of Health \& Human Services: Washington, WA, USA, 2012; Volume 9-11, pp. 161-167.

7. ATSDR. Case Studies in Environmental Medicine; U.S. Department of Health \& Human Services: Washington, WA, USA, 1992; pp. $1-28$.

8. Ajayi, O.S. Measurement of activity concentrations of $40 \mathrm{~K}, 226 \mathrm{Ra}$ and $232 \mathrm{Th}$ for assessment of radiation hazards from soils of the southwestern region of Nigeria. Radiat. Environ. Biophys. 2009, 48, 323-332. [CrossRef]

9. Khandaker, M.U.; Uwatse, O.B.; Bin Shamsul Khairi, K.A.; Faruque, M.R.I.; Bradley, D.A. Terrestrial radionuclides in surface (dam) water and concomitant dose in metropolitan Kuala Lumpur. Radiat. Prot. Dosimetry 2019, 185, 343-350. [CrossRef]

10. Gaafar, I.; Hanfi, M.; El-Ahll, L.S.; Zeidan, I. Assessment of radiation hazards from phosphate rocks, Sibaiya area, central eastern desert, Egypt. Appl. Radiat. Isot. 2021, 173, 109734. [CrossRef]

11. Sivakumar, S.; Chandrasekaran, A.; Senthilkumar, G.; Suresh Gandhi, M.; Ravisankar, R. Determination of radioactivity levels and associated hazards of coastal sediment from south east coast of Tamil Nadu with statistical approach. Iran. J. Sci. Technol. Trans. A Sci. 2018, 42, 601-614. [CrossRef]

12. Pavlidou, S.; Koroneos, A.; Papastefanou, C. Natural radioactivity of granites used as building materials. J. Environ. Radioact. 2006, 89, 48-60. [CrossRef]

13. Khandaker, U.M.; Asaduzzaman, K.; Bin Sulaiman, A.F.; Bradley, D.A.; Isinkaya, M.O. Elevated concentrations of naturally occurring radionuclides in heavy mineral-rich beach sands of Langkawi Island, Malaysia. Mar. Pollut. Bull. 2018, 127, 654-663. [CrossRef]

14. Xinwei, L. Natural radioactivity in some building materials of Xi'an, China. Radiat. Meas. 2005, 40, 94-97. [CrossRef]

15. Abu El-Laban, S.A. Some geological and geochemical studies in Abu Ramad Area, South Eastern Desert, Egypt. Ph.D. Thesis, Cairo University, Giza, Egypt, 2002; p. 274.

16. Arunima, S.; Lekshmi, R.; Jojo, P.J.; Mayeen Uddin, K. A study on leaching of primordial radionuclides $232 \mathrm{Th}$ and $40 \mathrm{~K}$ to water bodies. Radiat. Phys. Chem. 2021, 188, 109658. [CrossRef]

17. Monica, S.; Jojo, P.J.; Khandaker, M.U. Radionuclide concentrations in medicinal florae and committed effective dose through Ayurvedic medicines. Int. J. Radiat. Biol. 2020, 96, 1028-1037. [CrossRef]

18. Papadopoulos, A.; Christofides, G.; Koroneos, A.; Papadopoulou, L.; Papastefanou, C.; Stoulos, S. Natural radioactivity and radiation index of the major plutonic bodies in Greece. J. Environ. Radioact. 2013, 124, 227-238. [CrossRef]

19. Pagel, M. The mineralogy and geochemistry of uranium, thorium, and rare-earth elements in two radioactive granites of the Vosges, France. Mineral. Mag. 1982, 46, 149-161. [CrossRef]

20. Shahin, H.A.E.R.A. Zr-Y-Nb-REE mineralization associated with microgranite and basic dykes at EL Sela shear zone, South Eastern Desert, Egypt. J. Korean Phys. Soc. 2014, 3, 1-12. [CrossRef]

21. Raslan, M.F.; El-Feky, M.G. Radioactivity and mineralogy of the altered granites of the Wadi Ghadir shear zone, South Eastern Desert, Egypt. Chinese J. Geochemistry 2012, 31, 30-40. [CrossRef]

22. Clark, R.L.; Hickey, R.C.; Butler, J.J.; Ibanez, M.L.; Ballantyne, A.J. Thyroid cancer discovered incidentally during treatment of an unrelated head and neck cancer: Review of 16 cases. Ann. Surg. 1966, 163, 665-671. [CrossRef]

23. El Mamoney, M.H.; Khater, A.E.M. Environmental characterization and radio-ecological impacts of non-nuclear industries on the Red Sea coast. J. Environ. Radioact. 2004, 73, 151-168. [CrossRef]

24. Gaafar, I.; Cuney, M.; Gawad, A.A. Mineral Chemistry of Two-Mica Granite Rare Metals: Impact of Geophysics on the Distribution of Uranium Mineralization at. Open J. Geol. 2014, 4, 137-160. [CrossRef]

25. Thabayneh, K.M. Measurement of natural radioactivity and radon exhalation rate in granite samples used in palestinian buildings. Arab. J. Sci. Eng. 2013, 38, 201-207. [CrossRef]

26. AlZahrani, J.H.; Alharbi, W.R.; Abbady, A.G.E. Radiological impacts of natural radioactivity and heat generation by radioactive decay of phosphorite deposits from Northwestern Saudi Arabia. Aust. J. Basic Appl. 2011, 5, 683-690.

27. Guillén, J.; Tejado, J.J.; Baeza, A.; Corbacho, J.A.; Muñoz, J.G. Assessment of radiological hazard of commercial granites from Extremadura (Spain). J. Environ. Radioact. 2014, 132, 81-88. [CrossRef] 
28. Senthilkumar, G.; Raghu, Y.; Sivakumar, S.; Chandrasekaran, A.; Prem Anand, D.; Ravisankar, R. Natural radioactivity measurement and evaluation of radiological hazards in some commercial flooring materials used in Thiruvannamalai, Tamilnadu, India. J. Radiat. Res. Appl. Sci. 2014, 7, 116-122. [CrossRef]

29. Abbasi, A. Calculation of gamma radiation dose rate and radon concentration due to granites used as building materials in Iran. Radiat. Prot. Dosimetry 2013, 155, 335-342. [CrossRef]

30. Aykamiş, A.Ş.; Turhan, S.; Aysun Ugur, F.; Baykan, U.N.; Kiliç, A.M. Natural radioactivity, radon exhalation rates and indoor radon concentration of some granite samples usedas construction material in Turkey. Radiat. Prot. Dosimetry 2013, 157, 105-111. [CrossRef]

31. Sharaf, J.M.; Hamideen, M.S. Measurement of natural radioactivity in Jordanian building materials and their contribution to the public indoor gamma dose rate. Appl. Radiat. Isot. 2013, 80, 61-66. [CrossRef]

32. Amin, R.M. Gamma radiation measurements of naturally occurring radioactive samples from commercial Egyptian granites. Environ. Earth Sci. 2012, 67, 771-775. [CrossRef]

33. Sabbarese, C.; Ambrosino, F.; Onofrio, A.D.; Roca, V. Radiological characterization of natural building materials from the Campania region ( Southern Italy ). Constr. Build. Mater. 2020, 121087. [CrossRef]

34. Ravisankar, R.; Chandramohan, J.; Chandrasekaran, A.; Prakash, J.P.; Vijayalakshmi, I.; Vijayagopal, P.; Venkatraman, B. Assessments of radioactivity concentration of natural radionuclides and radiological hazard indices in sediment samples from the East coast of Tamilnadu, India with statistical approach. Mar. Pollut. Bull. 2015, 97, 419-430. [CrossRef] [PubMed]

35. Ravisankar, R.; Sivakumar, S.; Chandrasekaran, A.; Prince Prakash Jebakumar, J.; Vijayalakshmi, I.; Vijayagopal, P.; Venkatraman, B. Spatial distribution of gamma radioactivity levels and radiological hazard indices in the East Coastal sediments of Tamilnadu, India with statistical approach. Radiat. Phys. Chem. 2014, 103, 89-98. [CrossRef]

36. USEPA EPA. Radiogenic Cancer Risk Models and Projections for the U.S. Population; EPA: Washington, DC, USA, 2011. Available online: https: / / www.epa.gov/radiation/epa-radiogenic-cancer-risk-models-and-projections-us-population (accessed on 25 January 2021).

37. Qureshi, A.A.; Tariq, S.; Kamal, U.; Manzoor, S.; Calligaris, C.; Waheed, A. ScienceDirect Evaluation of excessive lifetime cancer risk due to natural radioactivity in the rivers sediments of Northern Pakistan. J. Radiat. Res. Appl. Sci. 2014, 7, 438-447. [CrossRef] 